\title{
Chapter 3 \\ Federalism and Inequality in Education: What Can History Tell Us?
}

\author{
Carl Kaestle
}

\begin{abstract}
This chapter assesses the history of government efforts in the United States to enhance opportunity in education and to suggest lessons from the past. We focus primarily on federal policy, keeping in mind that solutions must depend upon successfully blending the resources and prerogatives of the federal government, the states, and local school districts. This chapter takes a chronological look, starting at free public education's onset to provide a foundation for the problems of inequality we face today. It then moves through the expanding federal role in the post-World War II years, followed by the battles over desegregation and the focus on providing resources to disadvantaged students. It then discusses standards-based reform, with a focus on how we arrived at the No Child Left Behind law and the issues surrounding the Common Core. Title I of the Elementary and Secondary Education Act, which targets impoverished students, is reviewed in detail. The lack of connection between Title I assignments and family income level, as well as lack of connection between Title I assignment and performance on the National Assessment of Academic Progress (NAEP), renders research results inconclusive in judging Title I's effects, but given that NAEP does show increasing average scores for Black and Hispanic students as well as declining gaps between those groups and White students, the evidence is sufficient that the program should be continued and improved. The chapter concludes by drawing some generalizations about the federalist governance system and its relation to educational equity and offers suggestions on ways to move forward, including changes regarding Title I and the federal role in education.
\end{abstract}

Keywords Federal policy - Education - Achievement gap • Desegregation • Standards-based reform $\bullet$ Elementary and Secondary Education Act (ESEA) • Title I - No Child Left Behind (NCLB) - Common Core - School finance - Brown $v$. Board of Education $\bullet$ Civil Rights Act $\bullet$ English language learners $\bullet$ Bilingual education $\bullet$ Disabilities $\bullet$ Special education $\bullet$ Discrimination against women

\footnotetext{
C. Kaestle $(\square)$

Department of Education, History, and Public Policy,

Brown University, Providence, RI 02912, USA
} 


\section{Introduction}

This chapter assesses the history of government efforts in the United States to enhance opportunity in education and to suggest lessons from the past. We focus primarily on federal policy, keeping in mind that solutions must depend upon successfully blending the resources and prerogatives of the federal government, the states, and local school districts. Of course, initiatives do not always stem from the federal government. Sometimes the states are the innovators and become models for federal education initiatives. Also, the landscape is complicated because members of the executive, legislative, or judicial branches at each level can initiate action, sometimes opposing one another. Federalism is not simply a system of congenially shared responsibilities.

In fact, shared governance in education policy arouses the alter egos of federalism: centralism and localism. Localists believe that governance and authority should be largely local because decisions made close to home are more efficient, more responsive, and more democratic. They believe that centralized decisions are inefficient and intrusive. Centralists believe that some values are best initiated by the federal government, that the central government should promote practices that serve our notions of civil rights, sound education, and national priorities.

This chapter takes a chronological look, starting at the onset of free public education. It then moves through the expanding federal role in the post-World War II years, followed by the battles over desegregation and the focus on providing resources to disadvantaged students. It then discusses standards-based reform, with a focus on how we arrived at the No Child Left Behind law and the issues surrounding the Common Core. Following the chronology, I end by evaluating the outcomes of these reform efforts and offering suggestions on ways to move forward.

Throughout the chapter, the overriding strand of thought is examination of equal opportunity through these various periods, including equity in how resources are devoted to the poor and other populations as well as removing barriers such as segregation. The theme of developing a meritocracy has been a long-existing theme in America as well, increasingly so beginning in the 1950s. Overall quality of education, not just equality, is discussed in latter sections as well as it has entered the fray via standards-based reform and the focus on improving education at all schools for all students, not just closing achievement gaps.

In discussing inequalities in educational achievement, we should keep in mind a few thoughts. First, there are various types of inequities - in students' health, housing, income, and parents' education. Also, achievement gaps across race-ethnic and income groups are very resilient. To reduce them, it is logical to reach beyond the schools to think about educational disadvantage in terms of these inequities. Furthermore, if we measure success by our standards for equity today, in truth all past efforts will come up short; our concepts of inclusiveness today are much broader than before. Lastly, data for such comparisons were nonexistent until recent decades. Thus, when we say that the National Defense Education Act of 1958 
"worked," we do not mean that scores rose in science. More often the evidence is in photographs of children smiling in front of test tubes. In 1963, Francis Keppel, John Kennedy's new commissioner of education, complained to a friend that the Office of Education did not have a single scrap of data on learning outcomes. Although Senator Robert Kennedy insisted that the Elementary and Secondary Education Act (ESEA) of 1965 require accountability through testing academic achievement, it took the federal government over 20 years to implement Kennedy's mandate effectively. ${ }^{1}$

\section{Development of Free and Public Schools Through the Progressive Era}

\section{The Creation of Free Public School Systems, 1840-1860}

We begin with the states' creation of free school systems in the 1840 s, building upon local efforts. Traditional educational historians argued that the fountainhead of our public schools was the district school in small-town colonial New England. But that claim is inflated as some New England towns did not establish schools, and barriers existed from the outset. In towns with public schools, girls faced shorter sessions and lower expectations and were banned from the grammar schools and colleges. Most children of color were excluded at all levels, left unlettered, or taught by their parents. Children from poorer White families faced the barrier of "continuation school"- - a part of the school year that wasn't free.

The "common school" reformers of the 1840s reacted to some of these limitations. They wanted to attract as many students as possible into a single system, not just to equalize opportunity but for social stability through state-sponsored moral education and mutual understanding across class lines. Many wealthy families declined the invitation, but in general the common school reformers in the Northeast and the new Northwest gained their main objectives by 1860: free schooling supported by local property taxes, the consolidation of small districts into town systems, and some state-sponsored teacher training (Kaestle 1983).

This was not simply a top-down state initiative. Enrollments were increasing in the early nineteenth century before the common school movement. This was partly because of an increase in girls' education and partly because states encouraged towns to organize school districts and levy taxes for schools. In addition to these local initiatives and state actions, many states had access to funds that derived from federal lands. Nonetheless, until the mid-twentieth century, the lion's share of the funds for free public education was from local property taxes (Goldin and Katz 2008; Kaestle and Vinovskis 1980).

\footnotetext{
${ }^{1}$ For the accountability amendment by Robert Kennedy, and Francis Keppel's efforts to develop more reliable assessments, see Kaestle (Forthcoming). For an effort to reach back to earlier decades and estimate changes in students' reading ability, see Kaestle and Stedman (1987).
} 
The establishment of free public schools across the Northeast and the Midwest improved equality of opportunity in education. Enrollments, daily attendance, and the length of the school year increased. Of course, the remaining barriers for people of color, children with disabilities, and women are striking from today's perspective. Increased opportunity also did not immediately result in closer-to-equal amounts of education received by working-class children.

Two other factors led to unequal outcomes. First, school attendance was not mandatory, so bias existed due to working-class families reacting to their economic realities and their family culture, with children and teens working instead of attending class (Kaestle and Vinovskis 1980, 82-99). Second, unequal resources across districts meant different school quality and length of school year. Funding schools through local property taxes is one of the most abjectly unequal aspects of public education in the United States. It is still with us today, and rare among nations.

\section{5-1895: Expansion and Professionalization}

In the period of 1865-1895, public schooling underwent more expansion and professionalization. Urban school systems acquired professional superintendents and became the model for well-run schooling. Testing, long before the IQ vogue, served superintendents as a way to monitor quality among teachers and schools. Teacher training began in newly developed "normal schools" and shorter-term "teachers institutes." The effect on educational opportunity is not easy to quantify, but enrollments, attendance, and length of school year continued their upward trajectory. Toward the end of this period, public high schools outnumbered private academies but were still predominantly the preserve of middle class students, the children of professionals, shopkeepers, engineers, office workers, accountants, skilled craftsmen, and others (on testing, see Reese 2013; on the expansion of elementary education, and information on academies, see Goldin and Katz 2008, 129-62).

\section{The 'Progressive' Era: Redefining Equal Opportunity}

Local reformers praised their high schools as the "keystone of the arch," or the "capstone" of a "perfect system." Reformers praised these new secondary schools as an institution of meritocracy, free and open to all. High school students were predominantly female (about $60 \%$ ) in the late nineteenth century, though the increasing restriction of child labor in the manufacturing sector meant that more working-class boys stayed in school as the new century unfolded. The percentage of 14- to 17-yearolds in school grew from $11 \%$ in 1900 to $32 \%$ in 1920 and became the modal experience at $51 \%$ in 1930 (Simon and Grant 1970; on the development of high school, see Reese 1995; Krug 1964; Rury 2005, 84-89). 
As the proportion of youth in high schools increased, it became apparent that not all students were preparing to go to college. This generated a great deal of thought about what curricula were appropriate for students with different educational and occupational futures. These discussions occurred in an era when theorists of human behavior were placing great emphasis on heredity, when racism was increasing in social relations, and an imperialist foreign policy thrust the United States into the development of colonies. Standardized student testing moved from its mid-nineteenthcentury roots to its hereditarian embrace with IQ tests, all putting a genetic hue on the emerging version of meritocracy (see Reese 2013; Kaestle 2012, 93).

Educators talked about "hand minded" and "brain minded" children and their different needs. In an explicit revision of equal opportunity, they developed different curricula for different children. Reflecting a growing conviction among educators, Stanford's Ellwood Cubberley $(1909,57)$ declared that people should reject the "exceedingly democratic idea that all are equal, and that our society is devoid of classes."

Many saw the creation of collegiate, general, vocational, and commercial tracks as steps forward for democracy: These different curricula would augment equal opportunity by providing an appropriate high school education for everybody. This was the era of corporate capitalism; in this context, democracy required not only participation and citizens' education but also expertise, science, and efficiency. Whatever the merits of this new concept of equal opportunity-and we should not think it merely as a hypocritical justification for inequality - it was compromised by biased predictions of students' futures, too often arising from their race, gender, ethnicity, and social class.

\section{Expanding the Federal Role in Education (World War II to the Space Race)}

\section{The Postwar Years}

Before 1950 the federal government played a minimal role in elementary, secondary, and higher education. It had partially funded the early development of public schools in the states through land grants in the early nineteenth century, and it had expanded opportunity for college attendance by creating land-grant colleges in the late nineteenth century. It had also given modest support for the differentiation of curriculum through its vocational education grants beginning in the early twentieth century. For the most part, however, education funding and policy were almost entirely in the hands of the states and local districts. The federal share of local school budgets in 1950 was, on average, $2.9 \%$.

Congress made its first foray into federal education funding in 1941 with the enactment of what would be called "impact aid," which compensated communities that saw an influx of schoolchildren amid the swift expansion of tax-exempt military 
facilities. But the key major war-related federal activity in education was the Servicemen's Rehabilitation Act (1944), which provided educational support, housing loans, rehabilitation training, and other benefits to military personnel returning home after World War II. The principal beneficiaries of this "GI Bill" were White males, because many of its programs and program officers were biased against Black GIs and because the numbers of servicewomen were a tiny percentage of all returning veterans. For White males, however, it provided substantial opportunities in college or other education. It also helped to double the number of college graduates in the decade following 1945 (see Bound and Turner 2002, 784-815; Turner and Bound 2003.)

Liberal Congress members and the National Education Association lobbied for federal aid, not for programs targeted at particular educational goals but for construction, teacher salaries, or simply for spending at the discretion of local school boards. Their bills, however, were routinely defeated in the 1940s and 1950s, as they also were in the 1920s and 1930s. Opponents included southern segregationist Democrats, who feared that federal aid would be used to press for integration; Roman Catholic representatives, who supported their churches' position against federal aid to public schools; and conservative Republicans, who opposed federal aid as something intrusive and foreign-inspired. This effective Congressional alliance was dubbed the " $3 \mathrm{R}$ 's" of localism in education policy: race, religion, and "Reds."

It should be recognized, however, that not all opposition to federal aid was simply motivated by these negatives. The positive image of local control was shared by President Eisenhower, his friend James Conant-the most respected education reformer of the 1950s — and many local leaders. They saw local control as a spur to citizens' participation and support for public education, as well as a more efficient, responsive, and democratic form of governance. Unfortunately, those who championed local control of schools, either consciously or unconsciously, also favored inequality as well, not only because of racial segregation but because of vast disparities of per-pupil expenditures in districts with different property wealth.

\section{Education, the Space Race, and Meritocracy}

We have seen that at the secondary level educators had already established a notion of meritocracy in the early twentieth century, long before the advent of the SATs, which were designed to promote that goal. It was grounded in achievement testing, teachers' reports, guidance counselors' decisions, and the differentiated curricula of the "comprehensive American high school." By the early 1950s, many critics of the public schools focused on the weak version of Progressive education known as "Life Adjustment," which focused on practical tasks for the large middle group of students who were neither in the higher academic tracks nor in vocational 
education. ${ }^{2}$ This criticism took the high road of equality, demanding the same academic curriculum for all, but it had little effect on school practice. The professional devotion to Life Adjustment was substantial, from school district offices to the federal Office of Education. The idea that meritocracy meant different curricula for differently able students, a legacy of the Progressive Era, was deeply embedded in the schools.

Meanwhile the American science and technology community was growing anxious about academic learning in the schools as a matter of national security and national competition. The brief public scare following the launch of Sputnik into space by the Russians in 1957 energized these concerns. Through skillful politicking by the bill's handlers and some concessions to Catholic educators, the National Defense Education Act (NDEA) was passed the following year. It was not designed to equalize opportunity but to raise the academic quality of schoolwork in the sciences, mathematics, and foreign languages, especially for the most academically talented students. By turning attention away from the utilitarian Life Adjustment curriculum, however, it may have had some positive effect across a range of high school students. On the other hand, the grants required a $50 \%$ match by the local district, suggesting that wealthier districts were more likely to apply for NDEA grants, thus reinforcing inequality (on the passage of NDEA, see Urban 2010).

Historian David Gamson has argued that the NDEA was supported by educators around the nation not just because everyone was alarmed by the launch of Sputnik but because the programs of the NDEA were easily compatible with the aims and programs in the field. This was a startling interpretation at first, because journalists at the time and many historians since have emphasized that Sputnik shocked the schools into rethinking their flabby "progressive" curricula and introducing more academically rigorous courses in math, science, and languages. This is a half-truth. The other half is that several of the underlying assumptions and intentions were legacies of the Progressive era, when educators had invented the multiple-curricula high school, with an emphasis on testing and guidance, all of which was revived and advocated in 1959 by Conant's popular book, The American High School Today, the bible of the "comprehensive" high school (see Gamson 2007).

The NDEA was more important to the federal role in education than it was to expanding educational opportunity. There had been no federal grant programs generally open to all public schools except for vocational education. NDEA prevailed over a storm of opposition about the perils of federal aid to education, succeeding politically for several reasons. It abandoned the goal of the professional education organizations to get "general" aid with no requirements attached. NDEA was a "categorical" bill, like vocational education. It prescribed which subject areas were eligible for support. It specified the need for language labs. It supported area studies in higher education and instruction in languages generally not taught in the United States.

\footnotetext{
${ }^{2}$ The most widely debated assault was from Arthur Bestor, a historian at the University of Illinois, in his Educational Wastelands: The Retreat from Learning in Our Schools (1953). See Kaestle (1990).
} 
Congress was more receptive to this kind of bill. In contrast to general school aid, it gave the impression of accountability: dollars paid for programs established. It honored the state education agencies, which received the money and monitored the programs. Flexibility was great; accountability was slim. It also proved flexible. When advocates for history, English, home economics, and other subjects complained, Congress broadened NDEA in subsequent reauthorizations. Gradually, NDEA took on somewhat more of the look of general aid.

NDEA was a breakthrough politically, but it did not expand much in subsequent reauthorizations. It was popular with local school administrators, but the big professional lobby groups resumed their crusade for federal aid that would be more general and more generous. More importantly, by the mid-1960s, NDEA was overshadowed by the seemingly sudden shift of priorities between 1958 and 1964, when the Johnson administration was developing the next big education bill. It was focused not on the most academically talented children in the nation but on the most disadvantaged. The ESEA bill of 1965 became the ongoing omnibus education bill (Peterson 1983, 60, 70-76, 132).

\section{Desegregation}

Brown v. Board of Education of 1954 would prove the launching pad for wideranging changes in America even though shifts in school segregation patterns would prove glacial at the outset. The more activist period on desegregation dovetailed with Lyndon Johnson's adoption of a "War on Poverty" a decade after Brown, starting with the Civil Rights Act of 1964 and setting the stage for ESEA's Title I program in 1965, which targeted impoverished students but also worked against segregation.

\section{The Role of ESEA in Desegregation}

Johnson's sudden shift toward poverty was inspired by his ambition to achieve a domestic agenda surpassing his idol, President Franklin Roosevelt. It is an intriguing connection. Roosevelt's New Deal was constructed in the face of a collapsed economy, while Johnson's Great Society programs were made possible politically by a buoyant economy that raised all boats, as James Patterson (1996) has argued.

Although Johnson's advisers warned him they could not discern much support for poverty reform, there were some harbingers of concern for the disadvantaged. There was a flurry of attention to Michael Harrington's book, The Other America: Poverty in the United States (1962). Also, although the Brown decision on racial integration had languished in the court system for 10 years, it would prove to be a constitutional lodestone. More important was the rise to leadership of Martin Luther King and the escalation of the civil rights movement. 
The two most important legislative initiatives that applied to education on these two themes were Title VI of the Civil Rights Act of 1964, which forbade discrimination in any federally funded program, and ESEA's Title I, which was enacted the next year and provided funds for compensatory reading and math education in schools with a high percentage of families below the poverty level. Although the principal aim of Title I was to improve academic achievement of low-performing students in high-poverty schools, it was also used in tandem with Title VI to pressure school districts to eradicate racial segregation. The federal government threatened to withhold Title I funding from districts found to be deliberately segregating their students. The long-delayed desegregation effort now became the most coercive intervention of the federal government into state and local systems in our history (on the passage of ESEA, see Sundquist 1968 along with Eidenberg and Morey 1969; on the Civil Rights Act, see Orfield 1969; Graham 1990).

\section{Federal Action to Desegregate K-12 Education in the South}

It is well known that very little action was taken to implement the Brown decision between 1954 and 1964. In order to achieve a unanimous decision, Earl Warren wrote vaguely (and famously) that the Court expected that desegregation would occur with "all deliberate speed." The second Brown decision, in 1955, addressed the implementation of desegregation. The Court left enforcement in the hands of the federal district courts in the South. Many southern states and some southern courts willfully misinterpreted the Brown decision to require only that they would have to wipe laws that sanctioned segregation off the books. As other court decisions moved away from that minimalist interpretation, other southern school districts contrived procedures they called "freedom of choice." It combined elaborate bureaucratic delays with illegal intimidation of African-Americans who asked to enroll their children at White schools (on the massive resistance period, see Barley 1997; Webb 2005; Patterson 2001).

Following the passage of the Civil Rights Act, every school district in the country, North and South, was required to file an affidavit with the Office of Education stating either that no segregation was occurring in its schools or describing a plan to discontinue such segregation. The main targets of the Office of Education were school systems in the 21 states that had mandatory or optional legalized segregation, most of which were in the Old South and border states.

More than 10 years after the Brown decision, there were virtually no Black students attending schools with White students in the Old South. Some federal judges supported desegregating districts, but increasingly they did not. Court orders were issued requiring desegregation, but the wheels of justice moved slowly. On the executive side, some federal officers also delayed and compromised, but increasingly, federal civil rights officers supported efforts to desegregate. Johnson kept his distance from the issue but issued occasional statements of support for the effort. President Richard Nixon tried to go slow to protect his "southern strategy" for 
reelection by opposing busing for desegregation. But the machinery of federal enforcement, after more than a decade of inaction, was geared up to enforce the Brown decision by 1968 when the Supreme Court declared in Green v. Kent Co., Va. that "freedom of choice" systems would not be allowed if they did not result in actual integration. ${ }^{3}$

A profound transformation like school desegregation needed the combined efforts of the judiciary, the executive branch, and Congress. None of those branches took up the cause for the first decade. Under Johnson, the weak link was Congress, with its potent coalition of southern segregationists and conservative Republican. By the end of the first Nixon administration (1972) and into the Ford administration, both the White House and the Congress were ambivalent or resistant to desegregation, in particular to busing. Nonetheless, major gains were made in the South in the years between 1968 and 1974, driven partly by some key Supreme Court decisions, the efforts of local plaintiffs and civil rights organizations, and the widespread opinion in favor of integration among staff lawyers at the civil rights offices in the Department of Health, Education, and Welfare (HEW) and the Justice Department.

Although the courts were not very effective at implementation, they played an important role in clarifying issues and supporting the authority of the executive branch. The Supreme Court's declaration against "freedom of choice" plans was one turning point, as was its 1973 decision in Swann v. Charlotte-Mecklenburg (North Carolina), which insisted that busing was an appropriate remedy and was mandatory if other methods were inadequate. ${ }^{4}$ At this point, many resistant southern districts threw in the towel and opted for at least a nominal level of integration. These Court decisions accelerated the most dramatic change in the entire federal desegregation initiative: the abrupt decrease in the percentage of African-American students in the Deep South and border states who were attending schools that were 90-100 \% Black. That may not capture the essence of the ideal of integration, but it was the government's chief aim, and after almost 20 years of resistance, it happened quite rapidly. In 1968, the percentage of African-Americans in the South attending overwhelmingly Black schools was $77.8 \%$, and by 1972 , it had dropped to $24.7 \%$. Comparable figures for the shift from 1968 to 1972 for the other regions were as follows (Clotfelter 2004):

- Border states: 60.2-54.7\%

- West: $50.8-42.7 \%$

- Midwest: $58.0-57.4 \%$

- Northeast: $42.7-46.9 \%$

\footnotetext{
${ }^{3}$ Green v. County School Board of New Kent County (North Carolina), 391 U.S. 430 (1968).

${ }^{4}$ Swann v. Charlotte-Mecklenburg Board of Education (North Carolina) 402 U.S. 1 (April 20, 1971); see also Douglas 1995; Wilkinson 1979.
} 


\section{Obstacles in the North}

Federal efforts to desegregate school systems in the North (and West) came later and were less successful. The Office of Education, as early as 1965, began investigating four selected cities (Boston, Chicago, San Francisco, and Chester, PA) where citizens' groups had documented school board policies that contributed to segregation, beyond the impact of housing segregation. They argued that they could address the issue in the North on the basis of the Civil Rights Act, even though the states involved did not have laws sanctioning segregation. Title VI simply says that no program receiving federal funds could discriminate on the basis of race, color, or national origin.

Commissioner Frank Keppel, acting on the directions of the assistant HEW secretary for civil rights (with whom he disagreed), pressed the matter with the Chicago school board, enraging Mayor Richard Daley. Politics trumped the Constitution. Daley cried "local control" and reminded Johnson that he had delivered Illinois' Democratic vote for him. Keppel lost his job as commissioner. When Keppel's replacement, Harold Howe, proved to be equally energetic on desegregation, some former supporters of desegregation in the Congress became frustrated; they thought that the executive branch was becoming overly aggressive. Together with southern segregationists, they pressured HEW to "centralize" all civil rights matters across the department, removing Howe from the enforcement of desegregation. But despite new people in charge, the policy slowly moved forward in the South and, in a minor way, the North (an essential revision of the usual narrative about Keppel's Chicago debacle is Miech (n.d.); see also Kaestle (Forthcoming)).

Although northern school systems were more segregated than those in the South by the $1970 \mathrm{~s}$, four factors militated strongly against desegregation in the North: first, public and judicial confusion about what the term "de facto segregation" meant; second, demographic trends that made it logistically difficult for a district with a high proportion of non-White students to effectively desegregate its schools; third, Congressional and public weariness of the coercive tactics required to move recalcitrant districts toward integration; and fourth, the rising opinion of American citizens-including many African-Americans-that busing for integration was wrong. This opinion was reinforced by a shift among the Black civil rights leaders in the generation after Martin Luther King, who eschewed integration in favor of better resources in their community's schools.

As to the first barrier, many journalists and some jurists kept alive the distinction that Southern desegregation was de jure (enacted in law and therefore unconstitutional), while Northern desegregation was de facto, existing mostly due to housing patterns and thus out of reach of the Brown decision. Of course, the housing segregation itself was the result of pervasive discrimination by landlords of rental dwellings, real estate people, and developers, as well as by government agencies condoning "red-lining" and other discriminatory practices. Decisions within the education policy sector were also grossly discriminatory. Districts deepened 
segregation through their choice of new construction sites, determining bus routes, drawing attendance boundaries, and granting transfer rights.

In the early days of activism at the Office of Education, federal officials relied upon the Civil Rights Act to attack segregation in states not covered by the Brown decision. These efforts preceded by a few years the Supreme Court's important decision in Keyes v. Denver (1973). That case built upon the language and reasoning of various lower court judges who had declared that northern segregation caused by the decisions of local school boards was not de facto segregation but clearly de jure segregation and thus failed the test of the 14th Amendment's Equal Protection Clause just as clearly as the laws that were struck down in the Brown decision. Keyes cemented this understanding of northern segregation among the judiciary, though many people continued to argue that northern segregation was different and beyond legal remedy (Kaestle Forthcoming).

The second barrier to northern segregation was the rising percentage of students of color in large cities like Detroit and Newark. As long as desegregation enforcement was restricted to single school systems rather than metropolitan areas, heavily White suburbs escaped involvement in the desegregation of cities that were predominantly non-White. Absent a metropolitan strategy, the prospect of busing children of color around the city to integrate them with a small number of White children was neither logistically nor educationally reasonable.

That restriction was given the imprimatur of the Supreme Court in the Detroit case Milliken v. Bradley in 1974, which declared the suburbs not culpable. Milliken provided a tiny loophole to allow for metropolitan solutions, and there were subsequently a few such desegregation agreements reached voluntarily or with court encouragement, but Milliken generally proved an effective barrier to desegregating large urban systems. ${ }^{5}$ Thus, when federal courts generally recognized that northern segregation due to local policy decisions was de jure segregation, the Supreme Court declared that school boards in governmentally separate suburbs could not be held responsible for segregation in the central cities they surrounded.

In the 1980s and 1990s, the Supreme Court would demand clear evidence of intent on the part of northern school boards accused of deliberate segregation. Without such evidence, they lifted court supervision of those systems.

The third barrier to effective federal action on northern segregation was growing public weariness with the conflict and a shift of opinion about its merits. In 1972, according to a Newsweek poll, $58 \%$ of White southerners favored racial integration, but $74 \%$ opposed busing to achieve such integration. In the North it was $68 \%$ in favor of integration and $68 \%$ opposed to busing. When the question was framed as busing for integration "outside of local neighborhoods" in a Gallup poll of the early 1970 s, only $9 \%$ of African-Americans supported it. ${ }^{6}$

\footnotetext{
${ }^{5}$ Milliken v. Bradley, 418 U.S. 717 (1974). Also see Baugh 2011. The best book on the decline in desegregation efforts is Orfield and Eaton (1996).

${ }^{6}$ The percentage for Whites is from Newsweek (March 6, 1972). The African-American results from a Gallup poll are reported in Frum $(2000,252)$.
} 
Indeed, for some African-Americans, it was not simply an opposition to busing but disillusionment with integration itself and the feeling that it was the wrong solution. The generation of civil rights leaders that succeeded King included some prominent figures who questioned the proposition that the way to improve Black children's education was to have them go to school with White children. The Student Nonviolent Coordinating Committee expelled its White members and adopted a policy of Black Power. Floyd McKissick, director of the Congress of Racial Equality, sent his children to integrated schools in Washington, D.C., where they had "pages torn out of books, water thrown on them in the dead of winter, ink down the front of their dresses."”

Other African-Americans came to think it was demeaning for policy officials to imply that their children could not learn well unless they were in school with Whites. This position dovetailed with the movement toward Black Power. Historian Jack Dougherty found that when Black leaders in Milwaukee pressed hard for desegregation, the federal government had not yet decided what to do about northern segregation and was unresponsive. By the time federal officials focused on Milwaukee desegregation, they faced a divided Black community. Many Blacks had defected from integration to community control (Dougherty 2004).

\section{Assessing the Success of Desegregation}

Effects on School Composition These shifts in the early and mid-1970s did not quash the ongoing desegregation suits and investigations of the North and South. There was a certain momentum behind the 10 years of activism. Many civil rights officers in the Office of Education and the Justice Department still pressed on, notably David Tatel, director of HEW's Office of Civil Rights (OCR), in the late 1970s. But in the 1980s and 1990s the landscape had very much changed. A more conservative court removed court supervision of several cities despite continuing racial segregation, which the Court deemed to have not been caused by school board policies. The Court made it more difficult to document intentional discrimination and took the position that court supervision was not intended to go on indefinitely. ${ }^{8}$ The public and their representatives grew weary of the segregation battles. The proportion of children of color increased in urban school systems, and public policy drifted toward compensatory education and improving inner-city schools. President Ronald Reagan wanted to see less federal civil rights enforcement, and he succeeded.

The extent of desegregation in the regions of the United States, and the turning points of trends, can be seen in Table 3.1. The Northeast was hardly affected by the

\footnotetext{
${ }^{7}$ Quoted on CORE's website, "Floyd B. McKissick: 2nd National Director of CORE," http://www. core-online.org/History/mckissick.htm

${ }^{8}$ Missouri v. Jenkins 495 U.S. 33 (1990); Dowell v. Board of Education of Oklahoma City Public Schools 498 U.S. 23 (1991); Freeman v. Pitts 503 U.S. 467 (1992).
} 
Table 3.1 Trends in desegregation, 1950-2000: percentage of Black students in 90-100\% nonWhite schools, by region

\begin{tabular}{l|l|l|l|l|l|l|l|l|l}
\hline Region & $1950^{\mathrm{a}}$ & $1960^{\mathrm{b}}$ & 1968 & 1972 & 1976 & 1980 & 1989 & 1999 & 2000 \\
\hline Northeast & - & 40.0 & 42.7 & 46.9 & 51.4 & 48.7 & 49.8 & 50.2 & 51.2 \\
\hline Border & 100 & 59.0 & 60.2 & 54.7 & 42.5 & 37.0 & 33.7 & 39.7 & 39.6 \\
\hline South & 100 & 100 & 77.8 & 24.7 & 22.4 & 23.0 & 26.0 & 31.1 & 30.9 \\
\hline Midwest & 53.0 & 56.0 & 58.0 & 57.4 & 51.1 & 43.6 & 40.1 & 45.0 & 46.3 \\
\hline West & - & 27.0 & 50.8 & 42.7 & 36.3 & 33.7 & 26.7 & 29.9 & 29.5 \\
\hline U.S. & - & - & 64.3 & 38.7 & 35.9 & 33.2 & 33.8 & 37.4 & 37.4 \\
\hline
\end{tabular}

Source: After Brown: The Rise and Retreat of School Desegregation by Clotfelter, Charles T. Reproduced with permission of Princeton University Press in the format Book via Copyright Clearance Center

For updated figures, see Orfield et al. 2014

aExtrapolated from 1950-1954

${ }^{b}$ Extrapolated from 1960-1964

efforts of the federal government and other pressures to desegregate. The border states responded to the Brown decision rather substantially before the big push came from the federal government; by 1960, $59 \%$ were in schools with $90 \%$ or more non-White students. The states of the Deep South responded in two batches. Some districts went along fairly quickly in the mid-1960s, reducing the absolute segregation down to a situation where $77.8 \%$ of the South's Black students were still in strongly segregated schools in 1968. In the next four years, due to the efforts of civil rights workers in both the waning years of the Johnson administration and the first Nixon administration, they dramatically reduced segregation, to the point that only $24.7 \%$ of southern Black students were in $90 \%$ to $100 \%$ non-White schools. The Midwest and particularly the West reduced the percentage of Black students in strongly segregated schools, more than in the Northeast, perhaps because they were so much less urbanized and had relatively fewer large ghettos of African-Americans. (The figures here do not tell us about the expanding Hispanic population in the West and its relationship to racial isolation vis-à-vis Whites and Blacks.) Whatever the subtleties in the process, the West and the South had the lowest percentage of Blacks in schools with $90 \%$ to $100 \%$ minorities.

If we look at a different criterion, the percent of Black students who were enrolled in schools that had 50-100\% non-White students, the regional differences are less stark. In all five regions, somewhere between $67 \%$ to $78 \%$ of all African-American students were in majority non-White schools. The trends from 1980 to 2000 show modest increases in segregation on both measures considered here. Work on school resegregation since 2000 supports the trend toward greater isolation. ${ }^{9}$

In general, federal and state litigators have attempted to desegregate schools by working around housing segregation, urging busing, modified attendance boundaries,

\footnotetext{
${ }^{9}$ The data on Black students in majority non-White schools is also from Clotfelter (2004, Table 2.1, 56). Studies of resegregation since 2000 include Reardon et al. (2012, 533-47). On racial isolation more generally, see Massey et al. (2009).
} 
fair transfer policies, and other tactics. They achieved very substantial results in formal desegregation of schools in the Deep South and the border states. But by the time the courts had delegitimized the myth of de facto school segregation and federal officials moved to desegregate the cities of the North, the Milliken decision (1974) exempted the all-White suburbs of Detroit from responsibility for segregation in the city. This withdrew the essential tool that school integrationists needed. Furthermore, as Charles Clotfelter (2004) notes, in these latter years, White parents still retained multiple strategies to avoid integration by moving to suburbs, sending their children to private schools, or enrolling them in public schools whose tracking systems isolated the races, all of which were legal. Combating these counter-tactics was beyond the reach of the legal repertoire developed in the school desegregation initiative. In the face of these realities, the Supreme Court retreated from racial integration and the public turned away from the struggles to desegregate. The campaign in the North was lost.

The historical balance sheet on desegregation has assets and deficits. It repudiated legally segregated schools, expanded the definition of "legal" to cover the policy actions of local officials, and achieved its formal goal in the Deep South and border states. More children went to schools that included both Blacks and Whites. Despite very widespread resegregation over the past 40 years, we shall never return to the $100 \%$, school-by-school segregation that the South and border states had in 1955. But it is not as clear a victory as the eradication of separate railroad cars or other public facilities. With schooling and housing, the facts on the ground display continuing, profound segregation, some of it still due to discrimination, some to economic status, some to choices made by Whites and people of color.

Effects on Students The Brown decision was the Magna Carta of desegregation. The decision was cited in other cases involving other venues of public life. For many people Brown was the irreversible application of the Equal Protection Clause to deliberate segregation in American public life. But what were the consequences for the children who were integrated? In 2004, Clotfelter summarized his and others' research on some complex questions about the effects of integration. Increases in Black students' academic achievement were certainly not an automatic product of integration. Research has documented only modest improvements in Black achievement in reading correlated with desegregation, and only scattered increases in math. On the other hand, desegregation did not typically lower scores for White students, a common anxiety among White people reluctant to have their children integrated with Black students (Ibid., 187).

Many people hoped that increased interracial contact would foster understanding and tolerance. Clotfelter reports that when schools are thoroughly desegregatedwith real opportunities for students of different races to take the same classes, participate in clubs and sports together, and collaborate on projects-desegregation has often correlated with students making more friends across racial lines and expressing more tolerant views than students in other schools. But schools desegregated only through formal means left resistant Whites with many mechanisms for resegregation internally. 
Some self-reported attitudes about race showed more tolerance and engagement between 1975 and 2000 despite increased school segregation. Nationally there was an increase in the percentage who said they did "a lot" with students of other races, from about $33 \%$ to $42 \%$ for Black students and from $15 \%$ to $31 \%$ for White students, without controlling for the racial composition of their schools. Similarly, the percentage of high school students who said that if they had children, it would be desirable if those children would have friends of another race, increased from about $36 \%$ to $41 \%$ for Whites, and about $43 \%$ to $48 \%$ for Black students. These modest rises seem contrary to the increases in segregation and in any case could not demonstrate a causal effect stemming from desegregation. If these findings are technically valid, these more tolerant attitudes may simply illustrate that society-schools, media, and parents-had on average taught more children the propriety of such attitudes, all the while putting up with, or consciously supporting, more segregation (Ibid., 182).

All of these findings are "squishy." There is some evidence that integration done well - without resegregating students internally and providing a climate favorable for multiracial contact—can affect tolerant racial attitudes. Stated conversely, when Whites are segregated—school by school, within classrooms, by school tracking policies or by parents seeking private school attendance in predominantly White schools - school segregation is playing handmaiden to residential segregation in the United States. Together they have severe negative economic, social, and political consequences for African-Americans and other people of color. Racial isolation is also a deficit for Whites.

Some integrationists believe that school segregation is simply an offense to the Constitution and an indignity to those segregated, whatever the measurable results. But the consequences of Brown at the ground level suggest a pyrrhic victory. Today, our society blends pervasive segregation with a belief that the legal issues are settled and thus nothing can be done about it. To those who believed in the promise of Brown, this is not just frustrating but tragic. Gary Orfield, a tireless advocate of integration, said in 1996 that our society was "sleepwalking back to Plessy versus Ferguson," the 1896 Supreme Court case that sanctioned segregation while promising equality that was never given (Orfield and Eaton 1996, Chap. 12, 331). In sum, Brown and the desegregation campaign that followed 10 years later banned legally sanctioned discrimination and - through great effort-reduced actual segregation in the South and border states and in scattered areas across the North, Midwest, and West.

\section{The Challenges of Title I: The Early Years}

Several factors augured ill for the success of ESEA's Title I in improving the performance of poor students despite its enduring success politically over the decades. First, the alleviation of poverty was not a strong policy priority for the average American citizen or school superintendent. Also, there was little knowledge at the 
federal level or within the state and local levels about how to improve the academic achievement of these children. Congress spent the bulk of its attention debating how Title I money would be allocated, not how educators could improve poor children's education.

But Congress also did not devote much money to it. The Great Society programs were many in number and light on budgets. Johnson's War on Poverty was a big idea, but most of its programs were in the Office of Economic Opportunity, whose advocates fought hard to keep these programs experimental and small at first. HEW persuaded the President to locate ESEA in the Office of Education, but Congress did not give the resources needed to do the job. Advocates' hopes that budget appropriations would increase after the first year were confounded by the expansion of the Vietnam War.

Congress not only appropriated too little money but spread it across too many districts. Initially the entitlement was calculated by the number of students from families below $\$ 2000$ in family income or receiving state welfare. The latter was a concession to big states like New York, whose welfare payments exceeded \$2000. However, when those numbers were tallied, that figure was multiplied by a factor reflecting the existing per-pupil costs on average in the individual state, an inducement to get the support of richer states that spent higher amounts per child on education. Meanwhile, the initial definitions of poverty income levels were increased in order to make more attendance areas eligible. Soon, almost half the school districts in the country had some Title I schools. Liberal Democrats in future years would react to this by introducing "concentration grants," which allocated extra funds to the districts with the highest proportion of poverty families. Still, the redistributive effect of Title I was modest.

Title I also foundered because many districts felt little commitment to the stated purpose - to improve the education of children in poverty. They simply violated the law and used the funds for many nonapproved purposes. Scandals emerged within a year. Ruby Martin, former OCR director, and Phyllis McClure, of the NAACP's Legal Defense Fund, documented districts in which Title I funds were used to pay teachers and buy supplies that had nothing to do with Title I programs. Title I funds paid for disposal of sewage, renting an administration building, purchasing a heating system, buying buses for regular school runs, and constructing an instructional television studio for all students (Martin and McClure 1969, 6, 9-11, 13, 14, 21, 29). ${ }^{10}$

Gradually, the government brought such blatant violations of rules under control, but more subtle problems existed. Some schools used the funds only to bring the expenditures for poor children up on average from the existing unequal levels to those of more affluent children within a district. Federal officials found this "comparability" problem difficult to define and monitor. Other schools used Title I funds to replace local or state funds even though federal officials emphasized that Title I funds must "supplement" local amounts spent on these children, not "supplant" those local funds. Another knotty problem has been documented by economists:

${ }^{10}$ Thanks to David K. Cohen and Susan L. Moffitt for providing me with a copy of this report. 
Adding funds in a given year may seem like an advantage to the Title I programs, but those gains were often offset by subsequent reductions in local taxes for education (Gordon 2004; Cascio, Gordon, and Reber 2013).

It was virtually impossible for the federal government to ascertain whether the funds were reaching the stated goal, which was not just to spend the money on poor children but reduce achievement gaps between rich and poor. Few states had regular statewide achievement tests, and there was an intense phobia against developing federal tests. People widely believed that federal tests would drive curriculum, which was the prerogative of localities and the states. Senator Robert Kennedy insisted upon an accountability clause in Title I because he believed that schools had no idea how to accomplish its goals. However, that clause only required districts to devise whatever tests they wished to use and report them annually to the state, a provision that was inadequate on the face of it and was, in any case, widely ignored. ${ }^{11}$ As we shall see, important reforms were made in education legislation, and in Title I in particular, in the 1970s and 1980s.

\section{New Equity Issues Emerge in the 1970s}

Four important equity issues emerged in the 1970s - an effort to have the federal government encourage equalization of local-per pupil expenditures, which emanated from the Nixon White House and a Presidential Commission — and three others initiated by members of Congress working with citizens advocacy groups: improving opportunities for English language learners, women, and children with disabilities.

\section{Nixon Seeks to Equalize Expenditures}

Before moving ahead to the 1980s, it is worth looking at the issue of school finance reform, which blossomed as an issue early in the Nixon administration. Several different forces led to the establishment of a presidential task force on school finance. The administration had become interested in equalizing resources across districts, partly because they were so unequal but also because the administration had become committed to the improvement of inner-city schools as an alternative to extensive busing for desegregation.

The California Supreme Court had issued a decision requiring equalization of school resources in that state, but the school board in San Antonio, Texas, was

\footnotetext{
${ }^{11}$ On the debates and passage of ESEA, see Sundquist (1968) and Eidenberg and Morey (1969). For critical perspectives on its weaknesses, see Jeffrey (1978), and especially Cohen and Moffitt (2009), which emphasizes the paucity of educational resources at all levels and the loose policy levers in the federal system of educational governance.
} 
challenging such equalization just as the President's Commission on School Finance began its work. In its final report, the commission recommended a shift to full funding of education by the state. Districts would be allowed to raise up to $10 \%$ of the state allocation as a supplement and retain all authority over the spending of the district's entire allocation. In allocating money to districts, the state would consider criteria that included "differentials based on educational need, such as the increased costs of educating the handicapped and disadvantaged." The federal government would offer grants to states as an incentive for states to gradually shift to full state funding of schools and to "more nearly equalize resources among the States for elementary and secondary education."

The commission urged states to help local communities to offer early childhood education to children over 4 years old, and it urged state and local officials to reorganize districts to balance resources and favor a diversity of racial and economic background. The national interest, said the commission, included concentrating funds for low-income children, emergency school assistance for districts developing a more heterogeneous student body, and revenue sharing to states for special education (President's Commission on School Finance 1972).

Some of these goals had been around for some years, but the most radical and central policy shift, to full state funding, found no takers in the Congress. And in the Rodríguez v. San Antonio decision, the Supreme Court (in a 5-4 majority) declared that the San Antonio Board of Education had not violated students' rights under the Equal Protection Clause of the 14th Amendment. Equal expenditures in education, they said, was not a constitutional right. That did not preclude states or the federal government from taking steps to equalize per pupil resources voluntarily, but it put a halt to claims that the U.S. Constitution required it. The establishment of this barrier led many civil rights attorneys to pursue suits calling for equalization of resources within individual states, no longer arguing on the basis of the U.S. Constitution but on the explicit or implied rights of students based on state constitutions and laws. For this important and complex story, see Chap. 4.

\section{Bilingual Education}

The history of bilingual education is complex, with mixtures of tolerance and opposition, all the way back to British colonial America. Most states, however, gradually suppressed instruction in the native languages of English language learners. The League of United Latin American Citizens preached an assimilationist message but also promoted Hispanic cultural affairs and, more importantly, argued against the segregation and inferior treatment of Hispanic students from the 1920s through the 1960s. Indeed, the federal court decision in Méndez (1946) disallowed segregation of Spanish-speaking students. Loopholes allowing segregation for "educational" reasons kept this declaration from meaningful implementation, but it was widely considered as a precedent for the Brown decision. By the late 1960s bilingual education and desegregation became the twin aims of Hispanic activists. Senator Ralph 
Yarborough of Texas introduced a small, optional program to support English language learners. It became Title VII of the reauthorized ESEA in 1968. It passed without much support from Johnson, who did not like his fellow Texan and was preoccupied with the heavy financial burden of the Vietnam War.

These small beginnings for bilingual education coincided with the rise of the Chicano Movement, emanating mostly from the Southwest. Unlike earlier MexicanAmerican school reformers who focused on segregation and poor facilities, the Chicano organizations supported cultural reform of the school curriculum and the proud advancement of Chicano identity in all aspects of life. In strikes and protests in 1968 and later, Chicano leaders, including many high school students, demanded more bilingual teachers, more Hispanic counselors, and more respect for Chicano culture.

These ideas had some hold in Anglo politicians' circles. President John F. Kennedy's Committee on Equal Employment Opportunity released a report in 1963 declaring that the schools should have a curriculum that would "reflect Spanish as well as American traditions, and should hire teachers in both cultures." When the Nixon administration took office in 1969, he supported bilingual education, partly because he saw Hispanic votes in the offing, partly because he enjoyed supporting something that Johnson had not supported, and partly because he wanted to be seen as an innovator. OCR Director Stanley Pottinger was more liberal than Nixon was on most issues, and he sensed a green light on bilingual education. He issued a startling memo in 1970 arguing that because Title VI of the Civil Rights Act banned discrimination in any federal program, including discrimination against students on the basis of national origin, it actually required a curriculum that reflected students' language and culture. Pottinger did not have the resources to enforce such an opinion, and he did not insist that bilingual education per se was required. Still, the OCR memo sent a strong federal message (Pottinger 1970; on Hispanic struggles for more treatment, see Moreno 1999; San Miguel 1987; 2004; Strum 2010; Davies 2007, Chap. 6).

By now bilingual education was being advocated around the country. A strong bill passed in Massachusetts, and in the courts, a case called Lau v. Nichols was testing the language rights of non-English speaking students in San Francisco. Upon reaching the Supreme Court, the justices, in a unanimous decision, based their endorsement of students' language rights on the Civil Rights Act and Pottinger's memorandum. They declared "there is no equality of treatment merely by providing students with the same facilities, textbooks, teachers and curriculum" because "students who do not understand English are effectively foreclosed from any meaningful education." Like Pottinger's memo, the Court decision (1974) did not require bilingual education but insisted that all school systems had a responsibility to accommodate the learning needs of English language learners. However, when OCR issued a set of strong guidelines called the "Lau Remedies," the following summer, bilingual education was strongly favored. ${ }^{12}$

${ }^{12}$ Lau v. Nichols 414 U.S. 563 (1974); U.S. Department of Health, Education, and Welfare, Office of Civil Rights 1975, Appendix B. 
This preference for bilingual education reflected Congressional action in the Bilingual Education Act of 1974. Spearheaded by Ted Kennedy and Alan Cranston in the Senate, it endorsed the primacy of bilingual education with a bilingualbicultural approach. This was the apex of the reigning but fragile view of language rights and cultural pluralism. By the end of the decade, scores of dissenting reports and opinions had been registered.

The lasting effect of the Bilingual Education Act of 1974 was to confirm that accommodating students' English language learning was now mandatory. It also implied that bilingual education was not just a preferred but a necessary response to Lau. Finally, the act provided substantially more support for technical assistance and grants for research and development (\$68 million, about 10 times that of the Bilingual Act of 1968) (Schneider 1976; Stewner-Manzanares 1988).

Although bilingual education remained the predominant pedagogy for meeting English learners' language needs, there was a surge of negative criticism in the late 1970s and the 1980s. Many critics did not agree that bilingual education was superior to other techniques. Others launched philosophical salvos against accommodating the languages of non-English speakers. Some researchers pointed out the problems in "transitional" bilingual programs, which required subtle judgments about when a student should be transferred to regular English-speaking classes. In some cases, bilingual programs became isolated, and some children stayed in them longer than was effective for gaining content knowledge.

In the 1980s, a conservative President Reagan and a mixed Congress passed various bilingual education laws that prescribed what percentage of programs had to be bilingual and how many could be allowed through other pedagogies. The road beyond 1992 was mixed. Bilingual education had many critics but survived except in a few states that passed anti-bilingual legislation.

Many authorities in the 1970s argued that equal opportunity would not be achieved unless children, Hispanic and those of other national origins, could see their cultures reflected in the schools' curriculum. Though some Hispanic commentators have criticized bilingual programs, many others still believe in the ideal of bilingual-bicultural education in a pluralistic school environment. That hope was politically fragile, but there is no doubt that many public schools installed bilingual education programs, and some introduced a more pluralistic curriculum. The bilingual education movement, however flawed in some eyes, did move us in a more equal direction. A federal program that began modestly, with a small grants program, became obligatory by a sweeping but ambiguous Supreme Court decision.

\section{Title IX Bars Discrimination Against Women}

A second problem that received heightened attention in the 1970s was discrimination against women. Title IX of the 1972 Education Amendments forbade such discrimination in all federally funded education programs. Its effect in education 
was to add women to the list of groups already protected by the Civil Rights Act, which banned discrimination on the basis of race, ethnicity, or national origin.

Title IX received no opposition from the Nixon White House and enjoyed bipartisan support in the Congress. Some have thought that its quiet acceptance is mysterious, because it promised numerous changes in the traditional practices of schools and colleges. There were several reasons for this relatively easy passage. The women's movement, despite some setbacks, had laid the groundwork for wide publicity and considerable support for women's rights by 1971. The Congress and the White House were focusing their most energetic debates on busing for desegregation. After the bill's passage as the Education Amendments of 1972, when more politicians realized the implications of the law, there was much debate surrounding the drafting of regulations that would bring the brief language of Title IX to life. Most attention was focused on college admissions and school and college athletics. Compromises were made on undergraduate admissions, including exemption for single-sex colleges and on other matters, with HEW Secretary Caspar Weinberger in charge.

The regulations did not appear until 1975 . When they appeared, OCR was understaffed and ill prepared to respond to complaints. Education Commissioner Terrel Bell fretted privately about the impact of Title IX enforcement on local control. Weinberger was succeeded by Forrest David Mathews, who disliked bureaucracy and was opposed to a strong federal policy role in education. Thus the implementation of Title IX had barely begun when the administration of Democrat Jimmy Carter began in January 1977. Tatel, the OCR director, furthered the implementation of Title IX along with ongoing desegregation work. However, federal civil rights enforcement declined under the Reagan administration (Salomone 1986).

Nonetheless, Title IX had secured a permanent future, and some important policies and procedures were developed by the 1980s. All colleges and universities receiving federal aid were required to establish clear procedures for charges of sexual harassment. They were prominently posted and, in some cases, worked well. The dominance of women's athletics in discussions of Title IX has overshadowed equally important issues pertaining to access, discrimination, and sexual misconduct. All were important. Other issues received detailed attention from OCR, including gender balance among finalists for faculty positions (Ibid., as well as personal recollection of the author).

Assessing the success of Title IX is difficult. How much progress has been due to Title IX and how much to changing acceptance of women's capacities and rights? If there has been progress, what shall we make of continuing, endemic sexist behavior at the college level - from derogatory attitudes about women at prestigious graduate schools to an apparent epidemic of date rape at the college level? Title IX obviously still has a role to play in curbing these acts of discrimination and violence. Is the glass half full or half empty? Although uniform treatment and full equality of status still eludes us, there has been progress in increasing the proportions of women Ph.D. recipients in fields that were until recently male dominated, 
as well as rising percentages of women among college faculty and college presidents..$^{13}$

\section{Education of Children with Disabilities}

In the nineteenth century, almost no students with disabilities went to public schools. Most remained with their families, segregated from schools of any kind. Among those in institutions that were educational and not merely custodial, the emphasis was on blind and deaf children. In the cases of what were then called "mentally retarded," emotionally disturbed, or hyperactive children, some were committed to asylums where inmates were vaguely defined as "troublesome," "imbecilic," "incorrigible," or "truant." Toward the end of the nineteenth century many of these institutions adopted eugenic explanations of disabilities. Involuntary sterilizations were carried out on a large scale. As numbers swelled in these institutions, overcrowding, physical punishments, sexual assaults by staff, and physical restraints on the inmates occurred. Scandals caused little public concern until the 1970s. During the subsequent 20 years many were exposed and closed down.

A few outstanding institutions for children with disabilities in both the nineteenth and twentieth centuries developed educational methods and did other research in the field. In 1957, Governor Orville Faubus of Arkansas hired an able expert, David Ray, to direct the Arkansas Children's Colony. Ray lectured widely on the need to have such children going to public schools. He later became an adviser to Eunice Shriver, President Kennedy's sister, who lobbied for better government support for children with disabilities. Some states passed legislation requiring schools to admit some such students, but progress was slow. The Massachusetts law of 1972 would become a model for later federal action.

Two court cases helped publicize the issue and supported parents' claims that their children's civil rights were being violated. Members of the Pennsylvania Association for Retarded Citizens (PARC) claimed in 1971 that the state had violated the 14th Amendment's Equal Protection Clause when it allowed schools to reject admission to any child without at least a "mental age of five." Because state officials admitted that the law was wrong, the trial resulted in a consent decree, not a full-blown opinion. The three-judge panel simply said these children's rights had been violated and did not elaborate on the constitutional arguments. Expert witnesses had presented evidence that children with learning disabilities could benefit

\footnotetext{
${ }^{13}$ I am not aware of a comprehensive published history of Title IX, thus McCarthy (1991) is important. Ware (2007) organizes relevant documents. Other relevant works are Fishel and Pottker (1977, Chap. 5), which addresses the development of regulations for Title IX, and Costain (1979, $3-11)$.
} 
from the services of a free public school system. The Court directed Pennsylvania to expunge from its state code any barriers to the enrollment of these children. ${ }^{14}$

The PARC decision addressed children with intellectual disabilities but not those with other disabilities. One year later, suit was brought against the Board of Education of Washington, D.C. The first named plaintiff, 12-year-old Peter Mills, was expelled from fourth grade in a district elementary school as a "behavior problem." The District did not afford him a proper hearing or allow him to enroll in any other public school. The following year. D.C. authorities incarcerated Peter at "Junior Village," and the parents brought suit. Sketches of the other six plaintiffs showed similar histories. U.S. District Judge Joseph Cornelius Waddy ruled that the plaintiffs and all children with disabilities had rights under the Equal Protection Clause and could not be excluded from the public schools. School officials argued that it would be prohibitively expensive; Waddy disagreed. He ordered the District to "provide to each child of school age a free and suitable publicly-supported education regardless of the degree of the child's mental, physical, or emotional disability or impairment." 15

These cases stood as the legal landmarks of the education rights of children with disabilities. Nonetheless, some advocates were nervous that the upcoming trial in Rodríguez v. San Antonio might end with a denial of education as a right under the 14th Amendment. They campaigned instead for an endorsement of these rights under the Civil Rights Act.

This effort succeeded in the form of a one-sentence amendment to the Rehabilitation Act of 1973 known as Section 504. Modeled on the Civil Rights Act, it states: "No otherwise qualified handicapped individual in the United States . . shall, solely by reason of his handicap, be excluded from the participation in, be denied the benefits of, or be subjected to discrimination under any program or activity receiving Federal financial assistance." Young civil rights staff of Senator Harrison Williams (D-New Jersey) drafted this legislation. Their instincts about Rodríguez proved justified. In 1974 the Supreme Court declared, in a 5-4 decision, that the Constitution did not support a right to education. Nonetheless, Section 504 preserved the mantle of civil rights that surrounded special education. Like Title IX for women's education in 1972, Section 504 did not cause great controversy as a simple abstract statement because it was nestled in a bill full of specific requirements and programs (see Scotch 2001, 47-48).

The stage was now set for a comprehensive federal bill supporting special education. Mills and PARC were being widely cited. Many states were facing lawsuits on their basis. Other states were moving ahead voluntarily on these new responsibilities. In May 1973, the Washington Post estimated that there were about 7 million children with disabilities in the country. Of these, approximately 2.8 million were in public schools with special education services, a big rise from the 1960s. One million were excluded from public schools and were not in private schools. A half

\footnotetext{
${ }^{14}$ Pennsylvania Association for Retarded Children v. Commonwealth of Pennsylvania 334 F. Supp. 1257, U.S. Dist. (1971).

${ }^{15}$ Peter Mills v. Board of Education of the District of Columbia, 348 F. Supp. 866 (1972).
} 
million were in private institutions, many receiving no education. Finally, about 2.7 million children with disabilities were in schools where they received no special education. States were already alarmed at the costs, and tensions were arising about the relative share to be provided by the district, state, and federal levels. ${ }^{16}$

Williams' comprehensive Education of All Handicapped Children Act was debated in 1974 and passed in 1975. It had several main provisions. First, each child with a disability would have an individual education plan (IEP). Second, schools were directed to conduct education of the children with disabilities in the "least restrictive" environment, that is, in regular classrooms, to the extent feasible. This provision later became known informally as "mainstreaming." It was founded on the belief that children with disabilities as well as those without disabilities would benefit from daily contact and a normalization of relationships as well as access to the regular curriculum. However, it also brought tensions from teachers who believed that attention to children with disabilities detracted from paying attention to the other students and that some of these children were disruptive. Teachers also argued they were not trained to handle these responsibilities.

To get funds from this law, districts were required to submit a plan for appropriate education of all of their children with disabilities. Even if they declined funds from Williams' act, they were required to accommodate all children with disabilities because discrimination was forbidden by the Rehabilitation Act. The federal government proposed to fund the states for as much as $40 \%$ of the "extra" costs of special education (translating into about $20 \%$ of the total costs of the average special education student). However, federal appropriations were actually much lower than $40 \%$ (see Table 3.2). This shortfall led the hard-pressed states to complain that the law was an "unfunded mandate," but the authority of the federal government held steady: The obligation of the states was based on civil rights, regardless of federal funding.

Table 3.2 Funding of special education costs, percent shares, 1983 through 2010

\begin{tabular}{l|l|l|l}
\hline Date & Federal & State & Local \\
\hline 1983 & 7 & 56 & 37 \\
\hline 1988 & 6 & 58 & 36 \\
\hline 1994 & 6 & 55 & 39 \\
\hline 1999 & 8 & 47 & 45 \\
\hline 2010 & 9 & 47 & 44 \\
\hline
\end{tabular}

Sources: Parrish 2001, 4-12, Table 4; 2010 data from Baker et al. 2014

For end-of-the-century information, see New America Foundation (n.d). For a good discussion of these and other figures about relative share and real costs, see Aron and Loprest $(2012,110)$

\footnotetext{
${ }^{16}$ Bart Barnes and Andrew Barnes, "Special Education: A New Storm Center," Washington Post, May 29, 1973, C1; B. Barnes and A. Barnes, "Handicapped Pupils Face Schooling Crisis," Washington Post, May 30, 1974, D1. The Barnes's estimates of numbers of children with disabilities and their schooling categories came from Alan R. Abeson, spokesman for the Council for Exceptional Children.
} 
The regulations for the act were not formulated until nearly the end of President Gerald Ford's term. As with the Title IX regulations, implementation was delayed. The Carter administration took office in January, but the special education regulations went through a further lengthy consideration and appeared in the summer of 1977. By this time, special education had become an expanding item in school budgets, with the states and districts bearing most of the costs and straining under the imperatives of the law. There were also debates about mainstreaming; discipline with children with disabilities; whether severely disabled children should be mainstreamed; the overdiagnosis of disability for children of color; and other issues. Still, special education legislation had (and has) broad bipartisan appeal.

The rising percentage of students with disabilities among the total student population was substantial. The percentage of school students in special education in 1977 was $8.3 \%$; by 2005 it was $13.8 \%$ (U.S. Department of Education, National Center for Education Statistics 2015a). During that time the federal share of costs remained about level, while the state share decreased and the local share increased (see Table 3.2). It is this expanding percentage of students in special education, not rising costs per pupil, that has made special education the fastest growing budget item in most local districts. It arose over the past 50 years, starting from a situation in which only a tiny minority of children with disabilities were in public schools at all, to today, when it is a permanent and large reality in our schools. This development involved all three levels of the federalist system and all three branches, but it was led by federal courts and its advocates in the Congress, both pressed by interest groups of special education parents and special education professionals. Whatever its flaws, it was a historic shift, and, for the most part, a benefit to children with disabilities.

Another reform initiative addressed the profound discrimination experienced by Native Americans, but space allows only brief mention. These developments in policy governing Native American education, including the Indian Education Act of 1972, contributed to equalization of opportunity by recognizing Native Americans' justified desire for more autonomy in governing their educational institutions and having a genuine voice on commissions and in the newly created Office of Indian Education (for the history of education policy regarding Native Americans, see Szasz 1999; Hale 2002).

\section{The 1978 Reauthorization of ESEA}

Advocates and opponents of bilingual education, women's equity in education, and education for children with disabilities continued working through the complicated process of implementation, the approval of regulations and guidelines, and providing the relevant agencies with the needed resources to make a federal program work. In the meantime, the Democrats returned to the White House. President Carter had many problems on his hands, and in education, he was mostly preoccupied with creating a new Department of Education. Meanwhile, veteran staff at the Office of 
Education and in Congressional education committees carried on the development of a revised ESEA.

The impetus for a Department of Education arose during the 1976 election campaign, when Carter courted the National Education Association's support; in the process he agreed to support its longtime goal of creating a separate department with Cabinet status. Carter eventually focused on the promised department and gathered various West Wing staff to work on details, especially the issue of which federal programs would be transferred to it from other agencies.

Meanwhile, the reauthorization of ESEA loomed important. Much of the leadership for the reauthorization came from Marshall "Mike" Smith, assistant commissioner of education for policy. Smith was a veteran of ESEA purposes, policies, and problems and a veteran Office of Education official. The commissioner, Ernest Boyer, former chancellor of the State University of New York, advocated in Congress for ESEA along with HEW Secretary Anthony (Joe) Califano. But Boyer was otherwise mostly involved in the disputes about what programs should be in the new Department of Education, while Califano openly opposed losing the Office of Education, which he thought belonged in an organization that combined education with health and welfare matters.

Smith and his colleagues developed the Office of Education's proposed ESEA legislation and conferred with Congressional staff continually. Among the key House staff were Jack Jennings and Chris Cross. Jennings, a Democrat, was majority counsel to the House Subcommittee on Elementary and Secondary Education, and Cross, a Republican, was minority senior staff member. They worked well with each other and with Smith. A lengthy document emerged, went to the President for approval, and then went to the relevant Congressional committees for further negotiations.

Evaluations of Title I in the early 1970s had discovered widespread misuse of funds, questioned whether the funds were properly targeted at kids in high-poverty schools, and saw little evidence that the programs were working to improve academic achievement (McLaughlin 1975; Vinovskis 1999a). In response, Congress in 1974 commissioned a three-year study headed by Paul Hill at the new National Institute of Education (NIE). The legislative report by the House of Representatives' Committee on Education and Labor, when introducing the 1978 bill, stated that the NIE study had convinced them that the funds were now effectively targeted, explaining that while Title I provided only $5 \%$ of the elementary and secondary education budgets nationwide, many poor districts reported levels up to $17 \%$. As for results, NIE found that Title I students tended not to fall behind their "non-assisted peers." Part of the NIE research was a case study of 12 districts, which showed much better academic gains than in previous evaluations. Carl Perkins, chair of the Education Committee, concluded, "Title I has matured into a viable approach for aiding the disadvantaged." 17

\footnotetext{
${ }^{17}$ HR. Rep. No. 29-553 at 6-7. (Excerpt of a Report on the Education Amendments of 1978). Available online through HathiTrust at http://www.hathitrust.org/access
} 
The committee's optimistic report would not end criticisms of Title I's efficiency in raising students' scores. In fact, another study was ongoing at the same time. Called the "Sustaining Effects" study, it followed 130,000 students in 300 schools for three years. Study director Launor Carter pointed out the participation problems: Many poor children were in non-Title I schools that did not qualify as having a sufficient concentration of poor families. Conversely, many low-achieving students who were in Title I schools but were not economically disadvantaged were in Title I instructional programs. Furthermore, students with very low achievement levels got little benefit from Title I; those with somewhat higher achievement at the beginning benefited the most. These and other qualms caused Carter to say that Title I was not "a unified or coherent treatment program" and needed a "new program with more intensive and innovative techniques" to bring success to the lowest achieving students (Carter 1984).

The Office of Education staff, in consultation with education experts in Congress, came up with several substantial reforms for the 1978 authorization, working mainly with Congress but giving regular reports to the White House staff and getting their ideas vetted and approved by the Office of Management and Budget. Among these changes were allocating a higher per-pupil expenditure to Title I students in schools with a large concentration of high-poverty families (which Congress set at $55 \%$ ); pressing Title I programs to rely less upon "pullout" programs and to integrate Title I students into regular classrooms with special assistance; allowing schools with $75 \%$ or more percentage of children from homes below the poverty line to spend Title I funds on "whole school" programs and improvements; providing matching funds to states that had put money into their own compensatory education programs; providing better professional development for experienced teachers in the field; engaging in better planning and development of bilingual education; encouraging states to equalize resources among districts; deepening parental participation by requiring districts to pay for their transportation to and from meetings; and requiring districts to submit plans about the training of parent council members.

Beyond Title I, the 1978 Amendments had several other titles related to equal opportunity: Title II for basic skills improvement, Title VI for "emergency aid" to desegregating schools, Title VII for bilingual education, Title IX for women's education equity, and Title XI for Indian education. ${ }^{18}$ The collaboration and constant communication between Office of Education staff and key Congressional advocates was crucial in producing a reauthorization bill with bipartisan support.

\footnotetext{
${ }^{18}$ Education Amendments of 1978, 92 Stat. 2143 (Washington, D.C.: Public Law 95-561, 95th Cong (1978); interview with Marshall Smith, September 24, 2013; Cross (2014, 70-74); Jennings $(2015,35-42)$.
} 


\section{Education Policy and Civil Rights in the Reagan Administration}

Ronald Reagan was elected in 1980 over Carter on a platform that focused largely on cutting down on "big government." In the field of education, the Education Consolidation and Improvement Act (ECIA) of 1981 moved to decentralize and deregulate the federal role in education while spending less on federal aid. Its major sections were now called "chapters" rather than "titles." Chapter I became the new name for Title I for compensatory education of disadvantaged students in schools with high poverty. Education for children with disabilities also continued in separate legislation. But Chapter II of ECIA was a showcase innovation: a "block" grant. It pulled together 32 small federal programs. The items blocked in Chapter II ranged from the Emergency Schools Assistance Act (ESAA) for desegregation costs, to metric education, environmental education, and other small programs. The states received their share purely on the basis of population and were required to allocate at least $80 \%$ of it directly to districts. Districts were then permitted to allocate the Chapter II funds as they wished among the 32 programs.

This devolution of control came at a time when state and local budgets were tight, and the ECIA bill itself reduced allocations for many programs. There was less money for both Chapter I and Chapter II (in comparison to its 32 constituent programs separately) than had been the case a year before, so the states and districts had to make their decisions about Chapter II allocations in the midst of a funding crisis. Furthermore, Chapter II had a much smaller budget than Chapter I. In many districts, these 32 programs had added up to as little as $1 \%$ of the elementary and secondary school costs, although ranging upward in large city districts that had many more families in poverty and many remaining desegregation activities.

A strong shift of money from urban to suburban and rural, and a shift away from desegregation, resulted from the funding changes. Previously a large share of the funds represented by these 32 separate programs had gone to large urban districtspartly because ESAA was the largest program in the block, and partly because urban school staffs were more likely to apply successfully for grants. But Chapter II funds required no application. The money came just on the basis of school population.

The shift can be seen in these figures: Wilmington, DE, received $\$ 3.3$ million just from ESAA the year before the block funding; under ECIA, the amount of block funds for all Chapter II purposes the next year was only $\$ 1.7$ million. St. Louis and Kansas City received $\$ 7.0$ million between them under ESAA; the next year the entire state of Missouri received \$8.7 million for Chapter II overall (Verstegen 1985, 521). Another study showed that 20 urban school districts, including Atlanta, Buffalo, Boston, Chicago, and New York, collectively received $\$ 110$ million from the ESAA alone in 1980; the next year, they collectively received \$38 million for all the programs combined in the block grant (Salomone 1986, 179). Despite the overall reduction in ECIA funds, and perhaps because of the shift from urban districts, 
school officials in many rural and suburban districts praised ECIA as a modest return to local control, as it was intended to be (Turnbull and Marks 1986, 61, 63).

The Reagan administration proposed large cuts in other education programs. Education advocates in Congress strained against it, settling for budgets larger than the White House proposed but less than many had wished. Within these small annual increases, some of the flagship programs of the 1960s and 1970s were reduced. Rosemary Salomone writes that between 1980 and 1984, federal funding cuts, adjusted for inflation, were as follows: $9.3 \%$ for special education, $19.7 \%$ for compensatory education for disadvantaged students; and $39.8 \%$ for bilingual education (Salomone 1986, 180).

In addition to the shift of priorities in the small block grants-which worked disproportionately against desegregation aid — and targeted cuts in programs for compensatory education, bilingual education, and special education, there was also a slowdown of enforcement in civil rights suits. This was part of the Reagan platform to transfer authority in education to the states and districts. One of the effects of this philosophy was to diminish federal programs that had been intended to increase opportunity..$^{19}$ Overall, this was the last period when the federal portion of funding diminished.

\section{The Nation at Risk Report}

While federal funding was on the decline, a broad-based push for education reform was on the way. President Reagan's Secretary of Education was Terrel Bell, a veteran education leader from Utah who had served as U.S. Commissioner of Education during the Ford administration. He may have been the most liberal member of the Reagan cabinet, but he was a strong believer in local control. He had advised President Ford to veto the special education legislation in 1975 because he thought it was too costly and intrusive (Bell 1975). Bell had little stature with the President, but he was convinced that America's schools needed reforming, and he asked the White House to appoint a blue-ribbon commission to look into it. When the White House ignored his request, Bell appointed a department commission on his own authority.

The National Commission on Excellence in Education worked with data from researchers at the Education Department, who provided tons of information on the good news and bad news about schools in the U.S. However, two of the scientists on the panel, Gerald Horton, a physicist from Harvard, and Glenn Seaborg, a chemist

\footnotetext{
${ }^{19}$ I do not have data on expenses specifically for Title IX, which bars discrimination against women, as a part of the budget of the Office of Civil Rights in HEW. Salomone $(1986,180)$ reports that enforcement of Title IX was reduced during the Reagan administration, and that the Reagan administration tried to either block grant or zero budget the Women's Educational Equity Act, which complemented Title IX by providing funds to promote sex equity and eliminate sex-stereotyping in education materials. Women's advocacy groups succeeded in lobbying, and he signed a five-year extension of the program in 1984.
} 
at Berkeley, were not satisfied with the initial staff draft. Horton wanted something more decisive. He and other members crafted a theme of crisis, which framed the research data around alarming trends and gave them a slogan: A Nation at Risk. Journalists picked up on this eagerly. There was already much publicity about poor test results and their possible relation to America's competitive position in the world. Nation at Risk fanned the fires. The Department of Education counted 700 newspaper articles about the report in the first four months after its publication. Reagan met to congratulate the members. A side effect of this highly publicized report was that it weakened public and Congressional sentiment to abolish the Education Department (Vinovskis 2009).

However, it did not change the determination of the Reagan administration to back away from a federal role in education. In response to a President who said that education was the states' business and a federal report that said there was an urgent crisis, officials in the states took up the slack. It led to a decade of reform activity, resulting in new legislation in most states and capacity building in the state education agencies. The theme was excellence; the goal was to raise average test scores, not necessarily to reduce the gap between some groups and others.

The commission, along with several other reform reports, recommended more homework, higher graduation standards, more academic focus in schools, and better teacher preparation. Many states passed laws incorporating these recommendations. However, within three or four years, journalists and educators were bemoaning the failure of these reforms to increase test scores. The reform movement was fading. Its theory of action, plausible enough, was that if kids worked hard enough, and if teacher-training programs raised their standards, academic achievement would rise. However, that strategy did not work in the short run. By 1985 the National Governors' Association was calling for better testing and task forces to recommend better reforms.

\section{Reagan Faces Reversals: Hawkins-Stafford Bill of 1988}

In the waning years of Reagan's second term, Congress reversed some of his policies on education. This effort was led by Augustus "Gus" Hawkins, Democratic Congressman from Los Angeles and chair of the House Committee on Education and Labor, and his co-sponsor, Robert Stafford, a renegade Vermont Republican who believed in a strong federal role in education. Their bill deleted the signature provision of ECIA, the block grants under Chapter II. Hawkins-Stafford increased Chapter I spending staunchly but required the states to make gains on achievement and narrowing gaps. Any state that did not make its target two years in a row was required to review its districts' programs and supervise remediation. Equalization was the goal; tighter monitoring of test scores was the strategy.

The bill also strengthened the role of the National Assessment of Educational Progress (NAEP) by establishing an independent governing body, the National Assessment Governing Board, to set goals for what students should know and be 
able to do at various grade levels in various subjects. The new ESEA was not a panacea, however. The federal government still yielded to the states the job of setting performance standards, and there was great variability in how ambitious the goals were in different states. Nonetheless, as Jennings emphasizes, the emphasis in the Hawkins-Stafford amendments on accountability was a strong factor in the almost unanimous bipartisan support for the bill; also, the emphasis on standards helped lay the groundwork for the standards movement as the basis for school reform and accountability. ${ }^{20}$

\section{The Era of Standards-Based Reform}

\section{George H. W. Bush and the Onset of Reform}

As President Reagan's second term ended and George H. W. Bush was elected President, the country was looking for new answers to improve education. President Bush hoped to launch a partnership between the federal government and the states, but a Democratic majority in Congress short-circuited his legislative efforts. Meanwhile, the cadre of "education" governors was growing, and they began to edge toward the use of comparative state test results to spur reform. NAEP had launched an experimental state-by-state administration of the tests, which had the potential to rate states across the nation. Also, independent state-produced tests could be rated relative to the uniform NAEP assessments (Vinovskis 2008, 2009).

After his election Bush suggested a national education summit meeting, to which the governors readily agreed. Held in September 1989, the Charlottesville (Va.) Summit ended with the governors and the President agreeing to improve assessment and accountability. They also called for a set of national goals in education. Prior to the meeting, Governors Bill Clinton of Arkansas (Dem.) and Carroll Campbell of South Carolina (Rep.) co-chaired a meeting in which they noted the disadvantages of students of color and students from low-income families. Equality of opportunity had reentered the picture.

After the summit, the governors and the White House agreed upon six goals, several of which had strong implications for equal opportunity and equalization of results. The goals stated that by the year 2000, all children in America would "start school ready to learn"; $90 \%$ would graduate from high school; all students would demonstrate high competency in English, math, science, history, and geography; the

\footnotetext{
${ }^{20}$ For the provisions of the law, see Augustus F. Hawkins-Robert T. Stafford Elementary and Secondary School Improvement Amendments of 1988, H.R. 5, 100th Cong. (1988). For Hawkins, see "Hawkins, Augustus Freeman (Gus), (1907-2007)." n.d.; for Stafford, see Reagan Walker, "Stafford: Republican Rebel During Reagan's Revolution," Education Week, November 2, 1988, http://www.edweek.org/ew/articles/1988/11/02/08450045.h08.html, and essays on "HawkinsStafford Amendments," and "Targeting the Achievement Gap" in Federal Education Policy and the States, 1945-2009 (2009). On the importance of bipartisan support and accountability, see Jennings (2015, 48-49).
} 
U.S. would be first in the world in science and math; all adults would be literate and have the knowledge "to compete in a global economy" and become good citizens; and every school would be free of drugs and violence (Swanson 1991; on the novelty of the aspiration to have all adults gain high-level literacy skills, see Kaestle 1995).

These goals, of course, were optimistic statements. They were attainable only in part, and only if the reform movement could develop better theories about education reform and improved accountability systems. The period 1988 through 1992 was a very "yeasty" time for school reform ideas. NAEP tests at the state level now had the capacity to compare states' performances on basic skills, though hardly anyone thought they should be used as a national "test" for the evaluation of individual students or teacher accountability. The states at the front of the school reform movement were developing state-level standards and curriculum guides. Assessment experts were experimenting with more sophisticated "performance" assessments.

\section{Enter Systemic Education}

A key theory was articulated in a 1991 article by Marshall Smith and Jennifer O'Day called "systemic school reform." It crystallized several ideas that had been circulating in school reform circles and became a founding document for the standards-based reform movement. To be "systemic," said Smith and O'Day, the states must create content standards, performance standards, opportunity-to-learn standards (equal access to high-quality education), and student assessments, as well as foster teacher preparation and professional development that focus on the standards. To form a coherent program, all of these elements must be "aligned" (Smith and O'Day 1991). ${ }^{21}$

Historian Maris Vinovskis has analyzed the origins of this idea in the professional experiences of Smith and O'Day. As the director of the Wisconsin Center on Education Research, Smith was immersed in school improvement research, and his participation in the Consortium for Policy Research in Education reinforced his belief that the states should be the actors in developing standards. In 1990, Robert Schwartz, education director at the Pew Charitable Trusts, initiated the Pew Forum on School Reform, which included Smith. The forum began looking at exemplars of content standards from the various states and from abroad. O'Day, an expert policy analyst, was the associate director of the Pew Forum (Vinovskis 1999b, Chap. 7, 175-81).

Smith and O'Day emphasized the problem of underperforming poor and minority students, who were so often in underperforming schools. If reformers did not attend to this problem, not only would those students have unequal opportunity, but

\footnotetext{
${ }^{21}$ Marshall S. Smith and Jennifer A. O'Day 1999, "Systemic School Reform," in The Politics of Curriculum and Testing (London, England: Falmer Press, Politics of Education Yearbook, 1990): 233-67.
} 
the system itself would not be coherent. The idea of Opportunity to Learn (OTL) standards, which were designed to solve the problem of holding students responsible for meeting challenging standards when they may not have had adequate instruction in those standards, caused great controversy.

There were several problems with OTL standards. Some opponents said it was hard to imagine how one would operationalize indicators for OTL that would go beyond the many existing state policies like teacher certification, curriculum guides, and rules about class size. Some governors opposed them because of the estimated cost of establishing and maintaining OTL systems. Other opponents viewed them as a federal incursion into local control. Others said it would just delay the muchneeded standards-based reform movement. In the end, systemic reform without OTL standards became the backbone of the movement, which developed bipartisan support, and, despite great controversies, persisted as the unifying factor in federal and state education policy for 25 years, from the Clinton administration to the present.

\section{Standards-Based Reform Arrives on the Federal Agenda}

Governors and chief state school officers had been the prominent leaders in systemic school reform in the 1980s. Yet upon the election of President Clinton in 1992, the federal government reemerged as an education policy maker. Clinton was not shy to renew a strong federal role. He appointed William Riley, popular former education governor of South Carolina, as Secretary of Education and Smith as deputy in charge of drafting and promoting the legislative agenda in education. In addition to its enthusiasm for standards-based reform, the Clinton team focused on the problems of disadvantaged students.

The Education Department developed two bills during the first two years of his administration. The first bill was the reauthorization of ESEA. The Clinton administration renamed it the Improving America's Schools Act (IASA), but many old hands around Washington continued to call it ESEA. Also, the term "chapter" for a section of the law was returned to "title," the pre-Reagan term. IASA proposed to alter the Title I formula to focus resources on districts with the highest poverty concentrations. This lost in a close vote in the House subcommittee. Meanwhile, the Title I threshold for whole-school approaches was lowered from schools with $75 \%$ poverty families to $65 \%$. IASA introduced the new key provisions requiring districts to test all kids (not just those in Title I) with math and reading assessments that were geared to standards that states would be required to develop and implement. Other equity-related programs besides Title I remained: basic skills (Title II), aid for desegregation (Title VI), bilingual education (Title VII), women's educational rights (Title IX), and Indian education (Title XI). ${ }^{22}$

\footnotetext{
${ }^{22}$ On the legislative history of Title I in 1994, see Jennings (1998, 118-53). For a summary of all the titles, see "Summary of the Improving America's Schools Act," Education Week, November 9, 1994, http://www.edweek.org/ew/articles/1994/11/09/10asacht.h14.html
} 
The second bill was called The Goals 2000 Act. It specified how the states and the federal government would collaborate on systemic education, spurring many debates about the proper roles of the federal government. There were also equal opportunity concerns at stake. Smith and O'Day had focused attention on disadvantaged students and underperforming schools. There could be high standards for all children, and that became a mantra of standards-based reform.

The battle lines were typical: liberals vs. conservatives, and centralists vs. localists. But there were wrinkles. Some Democrats wanted national standards, some did not; some also wanted national assessments. Many Republicans supported standards-based reform but wanted the states to be the main actors and not supervised by the federal government. In the compromises that were hammered out, Goals 2000 proposed a system where states were expected to establish content standards, performance standards, opportunity-to-learn standards, and assessments. Each state was required to establish a board to carry out this work. A new national board, called the National Education Standards and Improvement Council (NESIC), would approve state plans, but only on a voluntary basis.

Even though Goals 2000 did not require states to submit their standards to federal authorities, many Republicans reacted negatively to the establishment of NESIC and it remained unfunded by Congress. As for the controversial opportunity-tolearn standards, they remained in the department's description of a proper systemic effort, but researcher Andrew Porter pointed out that there was little incentive for states to develop them, and even less incentive to subject them voluntarily to federal certification (Porter 1995; for the detailed arguments and debates about standards and federal authority in standards-based education, see Ravitch 1995; Jennings 1998; Kaestle and Lodewick 2007).

Republicans made gains in Congress and asserted themselves. They succeeded in abolishing NESIC, squelched the administration's suggestions for a Voluntary National Test, discredited a federally sponsored set of national history/social studies standards, and blocked the reauthorization of ESEA in 2000. The Democrats staved off some Republican assaults with help from some Senate Republicans who were not in tune with the more conservative program. ${ }^{23}$ Nonetheless, Goals 2000 established a framework that spread across the country and would remain the central reform instrument from that time to the present. Policy analyst Margaret "Peg" Goertz reported in 2001 that 49 states had content standards in reading and math, 48 of them had assessments to match, and 33 had developed accountability measures that went beyond student test performance. Paul Manna points out that several Republican governors and many business groups supported the standards movement. Furthermore, general public opinion favored the Clinton education agenda. While the administration's retreat from some issues may have looked like a defeat,

\footnotetext{
${ }^{23}$ Maris Vinovskis $(2009,111-20)$ presents a balanced account of education policy in the Clinton years, with many more details. See the book and sources cited there. See also, among the many books dealing with this period, Cross (2014); DeBray (2006); McGuinn (2006); Manna (2007); Jennings (1998); and Ravitch (1995).
} 
standards-based education was progressing in the states. Ironically, that formula would take on a more authoritarian federal face in the administration of President George W. Bush, a Republican (Manna 2007, 103, 152-54).

Peg Goertz reminded me recently of a metaphor for this significant policy success. Title I of IASA, with its requirement that all districts test all students on assessments that are linked to standards, could be considered the "stick," forcing the standards-reform framework on the districts, while Goals 2000 was the "carrot," the framework to help states and districts create standards-based systems. Conjuring up a different metaphor, Mike Smith said that the ESEA, with its requirements for school-wide testing and system accountability, was the "big engine" pulling all the other cars down the track. ${ }^{24}$

\section{No Child Left Behind: Its Trajectory Under George W. Bush and Barack Obama}

\section{Bush Launches New Federal Reforms}

President Bush's attraction to standards-based reform was similar to Clinton's. Both had been education governors and enjoyed the reputation of having successfully improved his state's schools. Bush was determined to continue the federal role in school reform, and his advocates fanned out to convince their conservative Republican colleagues that either they were out of step with public opinion or should give the President his preferences in education policy because the rest of his agenda was so attractive to conservative Republicans. But it took more effort than that. Sandy Kress, Bush's main education adviser, circulated the program first as a platform rather than as specific legislation. Bush's allies held meetings with carefully selected members of Congress. The campaign was skillfully done and unconventional. With Kress in charge, the administration and its Congressional allies bypassed the Senate Health Education and Pensions Committee, shunned the participation of education lobby groups, and ignored the staff of the Department of Education. In the wake of the attacks on the World Trade Center on September 11, 2001, many Congress members believed that they should work to pass effective legislation and not appear to be in disarray.

For Democrats, there were some attractive features in Bush's proposed No Child Left Behind Act (NCLB): an emphasis on improving failing schools and narrowing the achievement gap between racial groups, with disaggregated achievement test scores by group for each school available publicly, with some tough incentives and disincentives for schools that did not succeed. Senator Ted Kennedy endorsed the bill later in the process, hoping to get increased Title I money and achievement scores disaggregated by race-ethnic group. He got the scores but not much money.

${ }^{24}$ Margaret Goertz and Marshall Smith, personal communications. 
His co-sponsorship capped the image of a bipartisan bill (see DeBray 2006). But the goal of reducing achievement gaps was not solely the Democrats' property. Campaigning for the presidency, Bush vowed that his education policy would attack the "soft bigotry of lowered expectations." Speaking at Harvard in the second year of the Bush administration, Secretary of Education Rod Paige, himself AfricanAmerican, said that the achievement gap "is the civil rights issue of our time," and some leading civil rights lawyers like Christopher Edley of the Harvard Civil Rights Project and Bill Taylor of the Citizens Commission for Civil Rights supported NCLB for its tough approach and for setting an ultimate goal of reducing the gaps. ${ }^{25}$

The Bush team concluded that the Clinton enforcement of Title I had been slack and unproductive. The attempt to ensure that all states would link Title I tests to standards-related tests for the whole student population was still languishing in noncompliance. In response it produced the deepest intrusion into local control since desegregation. Some of its supporters in Congress and out in the states and the schools had second thoughts when they realized how much coercion was to be levied upon local school districts for not very much money. Schools were required to test all students in third through eighth grades annually. States were required to commit themselves to performance standards. Schools that did not come up to their adequate yearly progress (AYP) commitments would eventually be liable for "reconstitution," including sanctions as severe as having new leadership being appointed or being reopened as a charter school. This assumed that the states had the technical capacity to remedy poor performance, which was not always the case.

It began to appear that the rules would generate huge lists of condemned schools, because the end goals were set too high. Elizabeth DeBray (2006) wrote that the unrealistic goals and the concerns about the extent of federal leverage led to a "rocky start" for NCLB. The Bush administration softened some of the demanding features of the law but persisted in the end goal to have all children proficient by 2014. That, some test experts said, was impossible. Robert Linn wrote in 2005, "There is considerable evidence that gains in student performance on the tests tend to be greatest in the first few years after they have been introduced as part of an accountability system and then taper off in later years." Thus, those states that adopted low AYP goals in the early years, expecting to accelerate into higher achievement and smaller gaps later in the process, were working in exactly the wrong way. Said Linn, "It can be anticipated that the AYP goals, which are likely to be hard to meet in the early years, will become increasingly difficult to meet in the out years of the program" (DeBray 2006, 129-43, Rothstein 2004; Linn 2005).

In the latter stages of Congressional consideration, some staff on the Senate Committee on Health, Education, Labor, and Pensions did some research, simulating how many schools would be deemed failing in three of the states known for

\footnotetext{
${ }^{25}$ George W. Bush's speech to the National Association for the Advancement of Colored People, July 16, 2000, is quoted in "Bush Addresses NAACP Convention," ABC News, http://abcnews. go.com/Politics/story?id=123409; Paige is quoted in Cara Feinberg, "Rod Paige Offers High Praise for No Child Left Behind," Harvard University Gazette, April 29, 2004, 1; on Edley's support, see DeBray 2006; Taylor's support is documented in Linn (2005) and personal interviews.
} 
reducing the achievement gap: Texas, North Carolina, and Connecticut. Based on the AYPs, almost all the schools in these states would have been rated as "failing." Presented at a meeting within the administration, these data produced a "stunned silence," said a staffer. Another staff member said, "I left just wanting to cry" (Manna 2007, 124-25).

The Bush people and their allies rushed to adjust the AYP formulas, but the results were unsuccessful. Once the bill was passed and in the field, the Bush administration eased off, allowing different kinds of tests to be used and delaying deadlines. Paul Manna argues that the federal NCLB scheme actually relied on "borrowed state capacity" for its implementation, capacity which most states lacked. They realized this and pushed back. Almost all states had a nominal set of content standards by this time, but many were not coherent and not matched by an aligned assessment regime (Manna 2007; DeBray 2006). Standards-based reform had become a consensus position, with bipartisan appeal to centrists in both parties; Democrats on the civil rights left and conservative Republicans agreed with the Kennedy liberals and the Republican leadership in the Congress that there should be no amendments to the law at the end of Bush's first term, just administrative adjustments (Manna 2007; Cross 2014).

Some appraisals of achievement test scores suggest that there was a trough in which the achievement gaps widened during the end of the Clinton second term and for much of the first Bush term. Many factors could be responsible. Most states had not accomplished the reforms of the 1994 reauthorization, and districts were now faced with the Bush administration's new complex reform regime. In the second Bush term, he had an energetic Secretary of Education, Margaret Spellings, and the rules were clarified. Still, there was much criticism of No Child Left Behind (see Goertz 2005).

\section{Enter Obama and Duncan}

As President Obama entered the White House, the country was descending into a fiscal crisis and a major recession. State and local budgets were reduced heavily. As part of the American Recovery and Reinvestment Act (ARRA) of February 2009, the President and Congress put a large amount of federal money into high-priority areas to create jobs, relieve local and state budgets, and put money in the pockets of consumers. Secretary Arne Duncan's budget at the Department of Education was nearly doubled with an ARRA allocation of $\$ 97.4$ billion. The specific program areas receiving stimulus funding were State Fiscal Stabilization ( $\$ 48.6$ billion), college student Pell grants ( $\$ 16.5$ billion), Individuals with Disabilities Education Act funds ( $\$ 12.2$ billion), Title I programs ( $\$ 10.0$ billion), and formula grants and discretionary funds ( $\$ 10.1$ billion). Duncan and his staff had an unusual opportunity to fashion a new version of standards-based reform through these discretionary funds (Executive Office of the President of the United States 2009). 
The Duncan team had to decide what to do about No Child Left Behind. It was still the law of the land, but it was widely discredited for its negative incentives and unrealistic achievement goals. States and school districts were in a budget squeeze with predictions that it would get worse in the coming few years. And all of this fell to a new Secretary who had been a successful superintendent of schools in Chicago but had no experience in Washington. Several of his assistant secretaries had not yet been appointed when ARRA was passed. Meanwhile, the department's day-to-day business had to continue amid pressure to articulate a major reform strategy (U.S. Department of Education 2009).

With help from advisers around the country, Duncan and his staff developed a shift away from the NCLB mode of tight monitoring and negative incentives. In addition to Title I and other entitlement programs, the new strategy was to have competitive grants and reward the best state applications with extra funding to implement their plans, a positive incentive. The state plans had to comply with criteria set by the department.

From a critical perspective, there are (at least) two things to be questioned in retrospect: first, Race to the Top rewarded the 19 states deemed to have the best potential for effective reform, that is, the states with the best grant writers and the most broad support for their plan among their stakeholders. The 31 states that did not receive Race to the Top grants either opted out for various reasons or applied and were not chosen. The amounts were not trivial; in the first round, only two awards were announced, $\$ 500$ million to Tennessee and $\$ 100$ million to Delaware. Later awards were reduced as the budget dwindled. In any case, the competition left the children of those 31 states who did not receive Race to the Top awards without funds that those states might have used to improve their systems. This was the price for rewarding excellence. ${ }^{26}$

Second, the Education Department under Duncan took a very prescriptive stance. It insisted that every state applying for Race to the Top had to increase the number of charter schools and adopt pay-for-performance as part of salary decisions for teachers. Among the many possible policy options that one might have urged for mandatory implementation, many would have had a better basis in research than simply establishing more charter schools or using student scores in setting teachers' salaries-for example, access to early childhood education or carefully targeted class-size reduction. Research does not support the idea that simply increasing the number of charter schools will improve academic achievement. Charter schools perform about the same as public schools on a national average (C. Lubienski and S. Lubienski 2014). After some criticism from the field on this issue, the department began explaining that it meant to say it wanted more well-monitored, excellent charter schools, but the states got the first message loud and clear.

Similarly, the department created a list of strategies for rescuing failing schools. To get a federal grant for this work, applicants would have to choose one of the four strategies. Some people in the field thought that having to choose from a list of

\footnotetext{
26 "Delaware and Tennessee Win First Race to the Top Grants," U.S. Department of Education, press release, March 29, 2010, www2.ed.gov/news/pressreleases/2010/03/03292010.html
} 
strategies issued by the federal government foreclosed input from those who knew the particular circumstances, assets, and local constituencies of a given school or district. Jack Jennings studied hundreds of districts that had experience with turnarounds, some with federal grants, some not. He found very mixed results. Three of the federal strategies got low grades; one of them got much higher grades. It seemed to Jennings that the Department of Education was basing its confidence "on a hunch rather than on evidence."27

By the beginning of the second Obama term, most of the funds from ARRA were expended. Congress, meanwhile, was gridlocked by partisan conflict, so the No Child Left Behind legislation had not been reauthorized and, at the time of this writing, there seems little prospect of it happening before the end of the second Obama term. In response to this gridlock, the department simply relaxed some of the procedures of NCLB regarding failed deadlines for a district's AYP. This practice was formalized into a state-by-state granting of waivers, giving Duncan a new means of leverage. Each state receiving a waiver had to agree to a long list of the Department of Education's procedures that would substitute for the NCLB approaches. Forty-three states plus the District of Columbia had received waivers by November $2014 .{ }^{28}$

The "era" of standards-based education at the federal level has spanned the administrations of three Presidents: Bill Clinton, George W. Bush, and Barack Obama. Their approaches to school reform shared two features: first, all three put a very strong emphasis on schools with concentrations of economically and educationally disadvantaged children, abiding by the durable Elementary and Secondary Education Act. The central indicator of their success in these efforts was a slight but durable narrowing of gaps in student assessment results. This also took account of rising average scores by group, as well as retention and graduation rates. Second, all three placed the federal government in a strong relationship with the states and schools.

In all three cases, the strategy changes were influenced by reactions to the previous administration. Following Reagan's retreat from a strong federal role in education, Clinton asserted leadership in promoting standards-based reform. In the Bush administration there was widespread opinion that Goals 2000 had not worked well in the 1990s because so many of the states were not complying with Congressional decisions. Thus, it was time to get tough. In the Obama case, it was the opinion, again widely shared, that the Bush version of standards-based reform was too negative in its incentives. A swing toward positive incentives and showcasing success

\footnotetext{
${ }^{27}$ On Jennings' work, see Katherine Gewertz, "Restructuring Schools under NCLB Found to Lag." Education Week December 9, 2009; the quotation is from "New Study Questions Turnaround Strategies," EdNews Blog, http://blog.ednewscolorado.org/2009/12/09/new-study-questions-turnaround-strategies. For the department's account of the grant program as of 2015 , including a map indicating how the four strategies were distributed around the country, see "Turnaround Schools," Education Week, June 10, 2015.

${ }^{28}$ Allie Bidwell, "Education Department Drops New NCLB Waiver Guidance: The Waiver Extension Could Lock in Key Obama Administration Education Policies Past 2016," U.S. News and World Report, November 13, 2014.
} 
became the rhetoric; in reality, the resources that came with successful competition required states or districts to comply with many specific ideas generated by the Secretary and his top staff.

\section{The Importance of Title I}

\section{Background}

Title I has a historical importance as the program that led the way in federal efforts to improve educational opportunity. It has generated an ocean of research papers and policy arguments about whether to continue, improve, or abolish the program. Within the research and policy fields there is little consensus on how to interpret test scores such as NAEP in relation to Title I, and little consensus about what would constitute success (eliminating test score gaps across groups, reducing them, or keeping them from getting worse). The program is widely criticized despite increasing scores and slightly declining gaps between race-ethnic groups and decades of solid bipartisan support for the general idea of Title I.

Part of the dominance of Title I in such discussions has to do with the attraction to test scores and Title I's linkage to NAEP. Journalists follow suit, highlighting these test scores, although whether the emphasis on scores is appropriate is an open question. In contrast, consider the field of special education. Although special education's budget exceeds Title I in most districts, and federal support for it now rivals Title I, it does not have a simple annual set of achievement scores to report and receives less notice.

Some critics say that Title I has failed to close the achievement gaps. They also say there is no proof Title I is responsible for the modest narrowing of gaps in the test scores by race-ethnicity because NAEP does not actually identify Title I kids. Therefore, some say, Title I should be discontinued. Thus, Title I is an important topic; it would be an enormous decision to discontinue this durable but plagued symbol of the nation's commitment to improving the education of the children of poverty.

\section{NAEP's Relation to Title I}

To satisfy Title I regulations, states had to report academic assessment scores for their districts. As a concession to a long tradition of opposition to national tests, they could devise their own tests, but that meant the scores were not comparable across states. Since 1971, however, NAEP has been taking a representative sample of students across the country and assessing them all on the same material. Those scores were available only for national averages for the first two decades after 
NAEP's introduction, due to the same apprehension about a national test and undermining state prerogatives. By the 1990s, however, the states' opposition subsided and state-by-state assessments were developed on a trial basis in 1990. They became routine as of 1996.

NAEP prominently reports two kinds of data on achievement because they map onto the dual goals of Title I and standards-based reform: first, increases in the average scores for all students, and second, the gaps between the scores for students in the different race, ethnic, or income groups. The former is most closely related to the "quality" goal of education reform. (How good is my state doing as a whole compared to other countries or states, and how do my state's scores compare to our own scores for previous years?) The gaps between groups are most closely associated with the "equality" goal. (As the scores rise or fall for various subgroups, are the gaps decreasing or increasing between those groups?)

NAEP has kept comparable national figures since 1971 in reading and since 1973 in mathematics. Some changes were made in content and demands of the assessments during the 1970s and 1980s, but the Department of Education considers the trend lines reliable through to the present (this data series is now called LongTerm NAEP). However, as the changes in the test became more frequent and more fundamental, the NAEP board decided in 1990 to establish a second, more flexible series (Main NAEP) that would keep up with the changes and thus reflect the new work as well. Presently the Department of Education emphasizes the Main NAEP data for the ongoing release of scores and for interpretation of trends since 1990. The department states that the scores on these two series are not comparable to each other, but that within each series, the changes made in the test have not caused a break in the trend lines of the scores (U.S. Department of Education, National Center for Education Statistics. 2015b; Beaton and Chromy 2010).

\section{Long-Term NAEP: Trends and Interpretations}

For the period before 1990 we have only the Long-Term NAEP, and much analysis has been performed on these data. Nancy Kober, writing in 2001, presented achievement results from the Long-Term NAEP up to 1999. Kober noted that as the NAEP scores for White students in math and reading improved, so did Black scores. But the average scores for Blacks were rising more steeply. Graphs of Black and White scores in mathematics displayed a secular trend, steadily and gradually upward in scores, plus some gradual reduction in gaps by 1999 . The reading scores were more bimodal, starting with a large gap of 39 points in 1971, falling to a low gap of 18 points in 1988, and then increasing to a 1999 gap of 29 - still 10 points lower than in 1971.

Kober attributed the gaps remaining in 1999 partly to school factors for disadvantaged kids, such as less qualified or less experienced teachers; lower expectations; concentration of low-income students in some schools; school climate less conducive to learning; and disparities in access to preschool. Also, there are com- 
munity or home factors: the effects of poverty on learning, a legacy of discrimination, and limited learning supports in homes and communities (Kober 2001; Ferguson and Mehta 2004).

Going beyond NAEP, Geoffrey Borman and Jerome D'Agostino performed a meta-analysis of 17 major assessments from 1966 to 1999 . They wanted to test the notion that there had basically been no change over time in the effectiveness of Title I in raising achievement scores, which they say is the conventional wisdom. Their findings support the opposite view. The historical record also supports their view. The earliest years of Title I in the late 1960s and into the 1970s were characterized by weak enforcement, widespread abuse of rules by districts, and lack of consensus at all levels about how to improve the education of poor children in underperforming schools. By the 1980s oversight had improved, rules had tightened, and many more districts had accepted the challenge that had been tossed to them 20 years earlier.

Borman and D'Agostino found that Title I students were achieving greater gains in later decades than their similar peers not in Title I programs. To the argument that it still left substantial gaps between them and their non-Title I peers, Borman and D'Agostino argued that the Title I students "would have fallen farther behind" without Title I. To eliminate such gaps altogether would require the elimination of educational disadvantages beyond the school: poor nutrition, health, housing, and low parents' education, all in a negative, symbiotic relationship with poverty (Borman and D'Agostino 1996).

Ronald F. Ferguson reviewed the research on the effectiveness of the following reforms: reducing ability grouping and tracking; eliminating racially biased placements; providing more Black teachers for Black students; decreasing class sizes; and increasing the academic skills of teachers who predominantly taught students of color. For most of these he sees some merit. He summarizes in a clear and sensible conclusion: "Whether the Black-White test score gap would narrow if schools and teachers become more effective is uncertain. I believe it would. However, if the gap were to remain because all children improved, that too would be acceptable." (Ferguson 1998; see also Hedges and Nowell 1998).

\section{The 1980s and 1990s: Studying Actual Title I Students}

Despite some upward trend in NAEP scores in the 1980s and 1990s, Title I received much criticism. One interesting study with some positive findings was the "Sustaining Effects Study" headed up by Launor Carter in the early 1980s, relying on three years of data from the mid-1970s. Unlike NAEP data, their data distinguished between students in compensatory education programs (mostly Title I) and those who were not. Their sample included 120,000 students in 300 elementary schools. It could take achievement scores with participation in compensatory education and match them with the poverty status of families and race-ethnicity of the students taking the test. They compared Title I students with students who were 
described at the beginning as "needing" Title I but not assigned. They found the Title I students' scores higher. Very few datasets had as many variables as the Carter "Sustaining Effects" data, so it is not known in most studies of achievement gaps who had been in Title I; all that is known is students' NAEP scores and their raceethnicity, sex, and an indicator of family income (free lunch, partial free lunch, no free lunch) (Carter 1984).

By the 1990s there was much debate and publicity about achievement gaps, almost all of it around race-ethnicity. These debates were spurred by episodes of academic racism regarding race and IQ. As a result, the focus in Title I studies switched from family income to students' race-ethnicity.

In 1999, Maris Vinovskis reviewed the history of Title I. Vinovskis is a demographic historian and frequent consultant on both sides of the aisle, focusing on federal program effectiveness. With regard to Title I, Vinovskis judged that "efforts to radically change its approach or focus were ignored or defeated in the early 1980s." A Congressionally managed study called "Prospects" followed three cohorts over six years and concluded that Title I "did not appear to help at-risk students in high-poverty schools to close their academic achievement gaps with students in low-poverty schools." Like the Carter study, the Congressional "Prospects" data included whether students were in Title I or not. The authors reported that (in Vinovskis' words) Title I was "insufficient to close the gap in academic achievement between advantaged and disadvantaged students" (Vinovskis 1999a). I lack the expertise and the space here to evaluate the "Prospects" work. I note, however, that "eliminating" the achievement gap is a high hurdle. If disadvantaged students were not totally closing the gap between their scores and those of advantaged students, they might nonetheless have been keeping it from widening, and Title I might have been a factor. But gaps according to income, though they were not as emphasized, were flat or widening in recent decades, while those between race-ethnic groups were decreasing. (Reardon 2011; also see Jencks and Phillips 1998, Chap. 9).

\section{NAEP Score Gaps after 2000}

Analyses of Title I's achievement data after 2000 display similar score trends and the same diversity of judgments as those from the 1970s to the 1990s. Considering the large scope of this essay and the ocean of research literature about the effects of Title I, I shall present the Main NAEP scores for the period from 2000 to 2013 for the gaps by race-ethnicity that have been emphasized most in public discussions (Porter 2005; Clarke 2007; Dee and Jacob 2011; Carnoy and Loeb 2002).

Tables 3.3 and 3.4 display the Main NAEP scores by race-ethnic group in reading and mathematics, for the period from 1992 to 2013, for grades 4, 8, and 12. For example, fourth-grade reading scores for White students begin in 1992 with an average of 224, rising gradually but steadily to an average of 232 in 2013. Average scores of Black students on the same assessments go up and down during the 1990s, and then climb steadily to 206, thus reducing the White/Black achievement gap from 32 to 26 . The movements are modest and some changes are not statistically significant, but the trends continue across grade levels, as well as across reading and 
3 Federalism and Inequality in Education: What Can History Tell Us?

Table 3.3 Main NAEP reading scores, 1992-2013: White/Black and White/Hispanic gaps

\begin{tabular}{|c|c|c|c|c|c|c|c|c|c|c|}
\hline & 1992 & 1994 & 1998 & 2000 & 2002 & 2005 & 2007 & 2009 & 2011 & 2013 \\
\hline \multicolumn{11}{|l|}{ Grade 4} \\
\hline White & 224 & 224 & 225 & 225 & 229 & 229 & 231 & 230 & 231 & 232 \\
\hline Black & 192 & 185 & 193 & 191 & 199 & 200 & 203 & 205 & 205 & 206 \\
\hline W/B gap & 32 & 39 & 32 & 34 & 30 & 29 & 28 & 25 & 26 & 26 \\
\hline Hispanic & 197 & 188 & 193 & 197 & 201 & 203 & 205 & 205 & 206 & 207 \\
\hline W/H gap & 27 & 36 & 32 & 28 & 28 & 26 & 26 & 25 & 25 & 25 \\
\hline \multicolumn{11}{|l|}{ Grade 8} \\
\hline White & 267 & 267 & 270 & - & 272 & 271 & 272 & 273 & 274 & 276 \\
\hline Black & 237 & 236 & 244 & - & 245 & 243 & 245 & 246 & 249 & 250 \\
\hline W/B gap & 30 & 31 & 26 & - & 27 & 28 & 27 & 27 & 25 & 26 \\
\hline Hispanic & 241 & 243 & 243 & - & 247 & 246 & 247 & 249 & 252 & 256 \\
\hline W/H gap & 26 & 24 & 27 & - & 25 & 25 & 25 & 24 & 22 & 20 \\
\hline \multicolumn{11}{|l|}{ Grade 12} \\
\hline White & 297 & 293 & 297 & - & 292 & 293 & - & 296 & - & 297 \\
\hline Black & 273 & 265 & 269 & - & 267 & 267 & - & 269 & - & 268 \\
\hline W/B gap & 24 & 28 & 28 & - & 25 & 26 & - & 27 & - & 29 \\
\hline Hispanic & 279 & 270 & 275 & - & 273 & 272 & - & 274 & - & 276 \\
\hline W/H gap & 28 & 23 & 22 & - & 19 & 21 & - & 22 & - & 21 \\
\hline
\end{tabular}

Table 3.4 Main NAEP mathematics scores, 1992-2013: White/Black and White/Hispanic gaps

\begin{tabular}{|c|c|c|c|c|c|c|c|c|c|c|}
\hline & 1990 & 1992 & 1996 & 2000 & 2003 & 2005 & 2007 & 2009 & 2011 & 2013 \\
\hline \multicolumn{11}{|l|}{ Grade 4} \\
\hline White & 220 & 227 & 231 & 235 & 243 & 246 & 248 & 248 & 249 & 250 \\
\hline Black & 188 & 193 & 199 & 204 & 216 & 220 & 222 & 222 & 224 & 224 \\
\hline W/B gap & 32 & 34 & 32 & 31 & 27 & 26 & 26 & 26 & 25 & 26 \\
\hline Hispanic & 200 & 202 & 205 & 209 & 222 & 226 & 227 & 227 & 229 & 231 \\
\hline W/H gap & 20 & 27 & 26 & 26 & 21 & 20 & 21 & 21 & 20 & 19 \\
\hline \multicolumn{11}{|l|}{ Grade 8} \\
\hline White & 270 & 277 & 281 & 285 & 288 & 289 & 291 & 293 & 293 & 294 \\
\hline Black & 237 & 237 & 242 & 246 & 252 & 255 & 260 & 261 & 262 & 263 \\
\hline W/B gap & 33 & 40 & 39 & 41 & 36 & 34 & 31 & 32 & 31 & 31 \\
\hline Hispanic & 246 & 249 & 251 & 253 & 259 & 262 & 265 & 266 & 270 & 272 \\
\hline W/H gap & 24 & 28 & 30 & 32 & 29 & 27 & 26 & 27 & 22 & 22 \\
\hline \multicolumn{11}{|l|}{ Grade 12} \\
\hline White & $\mathrm{n} / \mathrm{a}$ & $\mathrm{n} / \mathrm{a}$ & $\mathrm{n} / \mathrm{a}$ & $\mathrm{n} / \mathrm{a}$ & $\mathrm{n} / \mathrm{a}$ & 157 & $\mathrm{n} / \mathrm{a}$ & 161 & $\mathrm{n} / \mathrm{a}$ & 162 \\
\hline Black & $\mathrm{n} / \mathrm{a}$ & $\mathrm{n} / \mathrm{a}$ & $\mathrm{n} / \mathrm{a}$ & $\mathrm{n} / \mathrm{a}$ & $\mathrm{n} / \mathrm{a}$ & 127 & $\mathrm{n} / \mathrm{a}$ & 131 & $\mathrm{n} / \mathrm{a}$ & 132 \\
\hline W/B gap & $\mathrm{n} / \mathrm{a}$ & $\mathrm{n} / \mathrm{a}$ & $\mathrm{n} / \mathrm{a}$ & $\mathrm{n} / \mathrm{a}$ & $\mathrm{n} / \mathrm{a}$ & 30 & & 30 & & 30 \\
\hline Hispanic & $\mathrm{n} / \mathrm{a}$ & $\mathrm{n} / \mathrm{a}$ & $\mathrm{n} / \mathrm{a}$ & $\mathrm{n} / \mathrm{a}$ & $\mathrm{n} / \mathrm{a}$ & 133 & $\mathrm{n} / \mathrm{a}$ & 138 & $\mathrm{n} / \mathrm{a}$ & 141 \\
\hline W/H gap & $\mathrm{n} / \mathrm{a}$ & $\mathrm{n} / \mathrm{a}$ & $\mathrm{n} / \mathrm{a}$ & $\mathrm{n} / \mathrm{a}$ & $\mathrm{n} / \mathrm{a}$ & 24 & $\mathrm{n} / \mathrm{a}$ & 21 & $\mathrm{n} / \mathrm{a}$ & 21 \\
\hline
\end{tabular}


math and across the White/Black gap, suggesting some progress. The scores and gaps follow parallel patterns for eighth graders, and for Hispanic students in 12th grade. The gaps in eighth-grade reading achievement of Black and Hispanic students, as well as for Hispanic students in Grade 12, are narrowed. In general, the upward movement is mostly observed in the assessments from 2002 to 2013, rather than in the period 1992-2000. ${ }^{29}$

In sum, the Main NAEP scores for 1990-2013 move gradually upward, with the three groups mostly parallel but narrowing the gaps slightly. These numbers support an argument made by various researchers: If the Black and Hispanic scores are keeping pace, and if those scores are affected by Title I programs, we should continue and improve Title I. The seriousness of the gap between Whites and students of color has been a central feature of discussions about equality of educational opportunity since at least the 1990s.

But do the NAEP scores by race-ethnicity tell us about Title I? As we have seen, the Title I money goes to individual schools according to the number of parents under the poverty line as defined in the legislation, but the instruction is administered to children selected by their low scores in math and reading, regardless of their raceethnicity or their families' income. Studies that actually track students in Title I instruction are few, and the ones mentioned above come to rather different conclusions (see Borman and D'Agostino 1996; and Carter 1984). Nonetheless, both recommend that Title I be continued and improved. As a historian interested in the history of educational opportunity, I hold this view. Many other researchers, some mentioned above, have made research-based suggestions for improving Title I programs (Carnoy and Loeb 2002; Dee and Jacob 2011; Ferguson 1998; Jennings 1998).

\section{Some Generalizations}

Before moving into the concluding sections of the report, I feel it is worth drawing some key generalizations about the evolution of the federal role in education and developments that laid the foundations for the reforms in play today.

\section{Three Eras in the History of the Federal Role in Education}

In the history of the federal role in education, there are "eras" that seem pretty clear. The first is from 1965 (or, if you wish, the National Defense Education Act in 1958) to 1980 , when you have several important and controversial additions to the federal repertoire in the direction of equity. From 1980 through 1988, we have the Reagan

\footnotetext{
${ }^{29}$ For mathematics, the fourth-grade scores for Whites move from an average of 220 (in 2000) to an average of 250 (in 2013). Black average scores keep pace, from 188 to 224, reducing the gap from 32 to 24. Hispanic fourth-graders scored an average of 200 in 1990, up to 231 in 2013, leaving the gap essentially level (from 20 to 19). In eighth grade, all three groups' average scores edged up from year to year, virtually parallel.
} 
presidency, the second "era." There is then a transition period under George H. W. Bush, whose inclination was to form a new partnership between states and the federal level but who instead got partisanship as the Democrats voted down his omnibus school reform bill. Thus, he falls between the second and the third era. That third era began in earnest with the presidency of Bill Clinton in 1993. From that time to the present, we have a unifying policy goal: standards-based education reform, spanning a Democratic President, then George W. Bush, a Republican, and Barack Obama, a Democrat.

\section{Conditions for Change}

The expansion of the federal role in education that began in 1965 coincided with the escalation of the civil rights movement, a mostly healthy economy, and a Supreme Court that, after a 10-year sleep, was ready to expand the authority of the Brown decision by asserting that the 14th Amendment's Equal Protection Clause required the courts to guarantee equal rights in education. During this time, savvy grassroots movements pressed for women's rights and the rights of children with disabilities, and Latino families demanded to see their cultures in their children's schools. This context helped these equity efforts, but still they weren't easy. Still, as James Patterson (1996) argues, the liberal agenda prevailed partly because a majority of people in the United States believed that the country could afford these reforms and that a rising tide would lift all boats.

\section{Congress as the Arena for Advocacy and Compromise}

Congress, especially the House of Representatives, was the arena where different interests and different regions began the process of advocacy and compromise. In the case of Title I, Congress spent most of its discussion time debating how the money was going to be divided, not on how the Title I classes might succeed. The resulting compromises ended with too little money spread over too many districts. These compromises were necessary for passage in Congress but impaired the program once in the field.

\section{Lack of Constitutional Authority as a Hindrance}

Beyond Congress, Title I advocates had to reckon with the federal role in education having no explicit authority in the Constitution and very little acceptance until the 1950s. That tradition guaranteed that any time there was a federal assertion of authority, it energized those who believed in local and state control. Localism and 
centralism, the "alter egos" of our Constitutional government, have never been far from educational policy making.

\section{States and Districts Forced to Focus on New Populations}

Lorraine McDonnell uses the three-era framework to make some fresh generalizations about the evolution of the federal role. Her depiction of the first era is relevant here. She urges us to think of it as a period of rather urgent interest in monitoring grants and making more specific rules for states and districts. She emphasizes an important point: The federal government was thereby forcing states and districts to focus on particular clients (English language learners, poor students, students of color, and students with disabilities), which was alien to the culture of schools (McDonnell 2005). The states and districts had sometimes distributed their resources in surreptitious, perhaps unconscious ways with deleterious effects: through assignment to ability groups, through tracking, and through the superior resources of some schools in White neighborhoods. Now they were asked to account for distributions, and they were told that money from some grants had to go, not just to some activity (like science education), but to certain students. This took time and money for school districts as well as an increase in the intrusiveness of state and federal officials; reformers, however, believed that these drawbacks would be outweighed by the fairness and effectiveness of the new categories and programs.

\section{The Numbers Game}

This was a time of fast development in budgets, accounting, and in the social sciences in order to judge programs by their output, not their input. Data became king. James Coleman's famous study of the relationship between academic test scores and race, class, school facilities, and other variables became a model for using achievement as a measure of program performance. The Pentagon's new Planning Programing and Budgeting system (PPBS) spread through the cabinet departments and out into other government levels under the influence of Secretary of Defense Robert McNamara. PPBS faded, but it had picked up on the changing standards of accountability. Frank Keppel, new Commissioner of Education for President Kennedy, was appalled that the Office of Education had almost no data on student learning, and he began to develop NAEP behind the scenes, doing it privately (because of the animus against a possible national test) with funds from John Gardner, then-chairman of the Carnegie Corporation in New York. Thus began the era of accountability that focused on actual performance of children in educational programs. It took years before federal and state officials could get legitimate, sufficient, standardized test data from thousands and thousands of school districts, many of them resistant, but in the late 1960s and the 1970s, the seeds were sown (see Dwyer 2005). 


\section{The Reality of Delays}

Delays in working out regulations and guidelines, pauses for changes in administrations, and other processes can add several years to the gap between the President's signing a bill and the agency in charge sending out notices of a law's activation date. These are the building blocks it takes to initiate a new major policy area from the federal level, as we have seen in our glimpse of the implementation of bilingual education, Title IX, and special education.

\section{Impressive Action Despite the Odds}

Given these pitfalls, it is impressive how many equity issues the federal government embraced and how much legislation it produced that affected schools. During the fertile time from the passage of ESEA in 1965 to the end of the 1970s, bilingual education, equal access and treatment for women students, equal access and treatment of children with disabilities, improvements in Native Americans' schools, and other programs took hold.

\section{The Federal Government's Agenda-Setting Role}

It is difficult to prove the benefits of these federal education programs, but at the very least, the federal government put them on the agenda with some regulations, expectations, and assistance. In none of these cases is it easy to document educational outcomes. But these items were, with some exceptions, not even on the radar at state and local levels before federal action. In cases where some of the states were ahead, as in special education, bilingual and other areas, federal advocates were able to benefit from this groundwork and use their national scope to generalize the concerns to other states. It's impressive to see that many new equity programs for new target populations developed in such a short time and in such a complicated system as federalism.

\section{The Half-Truth About the Federal Role}

The narrative of a relentless, engulfing federal control of education is a half-truth. The trouble with a half-truth is that half of it is true. The half that's true here is that there is a much greater presence of federal programs and rules in America's schools 
today than there was in $1950 .{ }^{30}$ Nonetheless, in 1965 the percent of local budgets provided by the federal government was $7.9 \%$, while in 2008, it was $8.0 \%$. From 1965 until 2009, it never went lower than $6.1 \%$ or higher than $8.3 \%$.

\section{Federal Action Can't Do It Alone}

As Jack Jennings reminds us, policy collaboration in a federalist system is not a zero-sum game. An increase in federal activity on school reform may occur at a time of increasing state reform activity. Even the local level may find itself creating more policy rather than less at the time that the role of the federal government and the states increase. Systemic reform, or Common Core, are complicated endeavors and require increased policy activity at all levels. ${ }^{31}$

\section{Not a Straight Evolution}

Obviously, given the example of the Reagan reduction of a federal role in education, the evolution is not just linear upward. People may argue about how abrupt and how deep Reagan's attempted reversal was. In this chapter I've emphasized the serious reduction in the budget, the small but symbolically important block grant in ECIA, and the reduction in civil rights enforcement. But Congress, including some Republicans, prevented some of the most severe cuts, saved Title I and other programs from being included in the block grant, and prevented President Reagan from abolishing the new Department of Education.

\section{From Laissez-Faire to Monitoring}

Quite apart from the drift toward student achievement scores, the Office of Education had to change its mentality beginning in the 1960s. Far from being avaricious bureaucrats anxious to control state education agencies and their school districts, the Office of Education had, for a century, been a sleepy agency with a strong inclination not to tell anyone what to do. It continually assured people in the field that it had no regulatory ambitions. This caused quite a staff crisis when the new breed came in. Keppel found a staff that was disinclined and untrained to monitor compliance. This applied very much to the desegregation effort, but there was also a

\footnotetext{
${ }^{30}$ This cute but important point is found in my lecture notes from Professor Eric McKitrick's course in mid-nineteenth century America, Columbia University, fall 1966.

${ }^{31}$ In my experience, this important declaration belongs to Jack Jennings, in one private chat, and at a couple of meetings. If it comes initially from Montesquieu, please forgive me.
} 
general disinclination to keep track of education program grants. Quick pressure to get new people and train old veterans shook up the Washington staff. After 1965, the Office of Education gradually became a policy and compliance agency. The vexing question was how much to trust local districts given a history of segregating schools, falsifying conditions, and misappropriating Title I funds. Finding the right balance between trust and compliance remains an ongoing issue, and it requires bureaucratic genius and diplomatic skills to do so.

\section{The Conundrum of the Federal Role in Common Core}

The third era, discussed at some length above, ended in an interesting conundrum. The three presidents of the third era, along with their Secretaries of Education and the U.S. Congress, created a federal policy of standards-based education, although the standards themselves were to be forged by each state. Then, after Clinton's forays into possible national standards and national tests were defeated, a group of former governors, educators, and businesspeople began talking about the possibility of a cooperative effort to develop such national standards and tests. This led eventually to the formation of a proposal sponsored by the governors and the chief state school officers to promote a compact called "Common Core." It is quite startling how the states acquiesced in the functions of the big, new collaboration of the National Governors' Association and the Council of Chief State School Officers, which is providing national standards and, through two national contractors, assessments to match. This will have a strong impact on the development of curriculum; indeed, vendors in the private sector have gone into action to offer curriculum materials that will be aligned to the national standards and assessments. The development of standards had until this time been in the hands of the states. In most of the states, reformers persuaded a majority of the public and the school leaders to consent to this new national system. The conundrum is twofold: How did this happen, and where does it leave the role of the federal government? We turn, then, to a brief presentation about the Common Core to understand the complex juncture at which we have arrived.

\section{A National Arena of Education Policy: Common Core}

There is an arena of policy formation and dissemination that is properly called "national," in which reforms move across state lines from district to district by informal, nonlegislative means but with some considerable influence. In the early twentieth century, this meant the consolidation of rural districts and the development of a multitrack high school curriculum. In the mid-twentieth century, it involved the articulation of the "comprehensive" American high school, which drew upon ideas from the early twentieth century. In the 1980s, it involved other reform 
ideas like increased standards and more discipline. Sometimes this "national" dialogue informed state policy makers just as much as federal legislation, depending upon the issue.

Common Core, a recent movement, is a very large and ambitious hybrid of "national" and "federal." The National Governors' Association and the Council of Chief State School Officers proposed nationwide content standards to be shared across states. Common Core advocates argue that it is not a federal but a "national" project. On the other hand, the Department of Education has put its considerable power and resources behind the Common Core. In the first Obama administration, candidates for the Race to the Top were required to join a consortium for multistate assessments, a key ingredient of Common Core. The department funded these two big assessment consortia. More recently the department withdrew NCLB waivers from two states that withdrew from participation in the Common Core. Thus, it seems accurate to say that this is a national project, initiated by the governors and the chiefs but strongly supported by the Department of Education (see Rothman 2011).

Even though the Common Core is mostly the work of the governors and chief state school officers and their staffs, it is nonetheless a strong assertion of authority exercised by a national group over traditional state authority in the area of school curriculum planning and testing. Advocates emphasize that content standards are not the same as curriculum (indeed they are not) and that Common Core provides content standards, not curricula (also true). But planning a school program (including the curriculum) is much influenced by the standards; furthermore, having also agreed to assessments from multistate consortia, the states will experience another strong interstate effect on their curriculum.

Many advocates think that this is an arrangement worth making, usually justified on quality and capacity grounds, which are unevenly distributed across states. Common Core advocates argue that academic performance will be upgraded by adopting these high standards and common assessments. Still, most of what people feared about "national tests" in earlier debates applies here: The consortia have already made compromises about tests of higher-level abilities because assessing these abilities requires more complicated technology and more test time, something that some states want and others do not. We shall see how it plays out.

\section{Equality and Quality With the Common Core}

Common Core emphasizes improvement in the quality of the standards. It includes much more analysis and other higher-order skills. This is laudable and exciting but also raises anxieties. Teachers in many states feel the implementation schedule is far too rapid and that they have not had sufficient professional development to teach to the standards well, especially because for many teachers the test scores will count in their performance evaluations. The other source of opposition to the Common 
Core is from local-control conservatives who are beginning to make Common Core a major issue in some states.

The possible effects of the Common Core on equity and disparate impact is not receiving as much attention as these other concerns, but it is crucial to the subject of this chapter: How functional for equal opportunity is the coming realignment of authority under the Common Core? Will children from low-income families and children of color be negatively impacted by the new, high demands of the Common Core? Will their teachers be as ready to teach to the Common Core standards as the teachers of more affluent children? Will our underperforming schools be able to teach effectively to these more demanding standards, with less experienced faculty and many children under the stresses of poverty and racial bias? In any case, the kaleidoscope of federalist governance seems to be turning to a new pattern. It will be fascinating to see what kind of a picture we get in five or six years, when the pieces come into clearer focus at the federal, state, and local levels. In particular, we will be interested in how the new alignment of initiative and authority will serve efforts to broaden educational opportunity and reduce gaps in academic achievement.

\section{Federal Funding: A Final Overview}

Before engaging in some policy suggestions, it is worth doing a broad review of the federal funding picture of education to provide an overview of the federal portion's size relative to state and local contributions. What appears to be a substantial expansion of the federal role in education occurred during the 50 years following 1965 . This period was marked by a generally expansive economy, bipartisan cooperation, the civil rights movement, the augmented role of the United States in a turbulent world, the growing importance of education in the economy, the skills of education reformers in the Congress and the executive agencies, and the strong roles of advocacy groups on education, both traditional and new. But how big an expansion was it?

Table 3.5 displays the changing share of school districts' expenses paid by local, state, and federal government. From these data we can see a prevailing increase in the federal share during this period of strong increase overall in the context of the long-term trends from 1920 to 2012. The downturn in the 1980s was due to policy preferences of the Reagan administration, though resisted with some success by supporters of education in the Congress. The peak, from 2010 to 2012, was due to emergency funds to the Department of Education from Congress in the wake of the 2008 economic crisis. We can assume that those percentages will decrease when the official statistics are posted for 2013 and following.

In the big expansion in the 1960s and 1970s, the federal share of local dollar expenditures grew from 4.4 to $9.8 \%$, about double. But is that a lot of money? It's worth pointing out that federal dollars are the kind that local administrators want because they are almost all devoted to new kinds of learning, new clients, and 
Table 3.5 Federal, state, and local share: public elementary and secondary school budgets

\begin{tabular}{l|l|l|l}
\hline Year & Federal & State & Local \\
\hline 1920 & 0.3 & 16.5 & 83.2 \\
\hline 1930 & 0.4 & 16.9 & 82.7 \\
\hline 1940 & 1.8 & 30.3 & 68.0 \\
\hline 1945 & 1.4 & 34.7 & 63.9 \\
\hline 1950 & 2.9 & 39.8 & 57.3 \\
\hline 1955 & 4.6 & 39.5 & 55.9 \\
\hline 1960 & 4.4 & 39.1 & 56.5 \\
\hline 1965 & 7.9 & 39.1 & 53.0 \\
\hline 1970 & 8.0 & 39.9 & 52.1 \\
\hline 1975 & 9.0 & 42.0 & 49.0 \\
\hline 1980 & 9.8 & 46.8 & 43.4 \\
\hline 1985 & 6.6 & 48.9 & 44.4 \\
\hline 1990 & 6.1 & 47.3 & 46.8 \\
\hline 1995 & 6.8 & 46.8 & 46.4 \\
\hline 2000 & 7.3 & 49.7 & 43.0 \\
\hline 2005 & 8.3 & n.a. & n.a. \\
\hline 2008 & 8.0 & 48.0 & 44.0 \\
\hline 2010 & 9.5 & 46.7 & 43.8 \\
\hline 2012 & 13.0 & 43.0 & 44.0 \\
\hline & 12.3 & n.a. & n.a. \\
\hline
\end{tabular}

improvement of instruction; in contrast, much of the remaining approximately $90 \%$ is largely needed for inflexible costs such as building and maintenance, salaries, student transportation, supplies, and similar necessities. So federal money has two rather large impacts: It provides program money and it allows the federal government to influence the agenda of the schools and require some accountability.

Although it is well to remember that the lion's share of the cost of public education falls to the state and local resources, opposition to the growing federal role is not about money as much as it is against new programs that require changes, rules, and accountability that infringe on local control. Whatever the objective of the federal initiatives - desegregation, better science classes, teacher evaluations, improved education of disadvantaged children, or adopting the Common Core-objections to federal assertions can also be justified on philosophical bases that are deeply ingrained in our history and our political preferences about how democracy best works in a very large country.

\section{Some Policy Suggestions}

This chapter has taken a broad look at the federal role in education, particularly about issues of equity. It has looked in detail at efforts to raise the achievement of poor children and those of color and ethnicity, as well as improving education for 
English language learners, women, and children with disabilities. Now, I offer some policy suggestions for ways to move U.S. education forward.

\section{Reassessing the Federal Role}

First, we should de-emphasize the role of the federal Department of Education in K-12 standards-based reform from defining and enforcing the details of school reform to a collegial support role. The states and districts will have an unprecedented challenge to implement the Common Core in addition to their other duties. Common Core has created a host of new policy questions that must be made by states and districts, not by the federal government or the Common Core national administration. These include which assessment system to choose; how to phase in these new assessments and standards into already complex systems of curriculum, testing, and accountability; how to produce or purchase curriculum materials that will serve their needs and comport with Common Core standards; how to provide the requisite teacher education and professional development; and how to guarantee that students in the least effective schools will have equal access to what they need to achieve in the Common Core. Given the importance of these decisions, which will manifest themselves differently in the various states, it may be an opportune time to reconsider the relationship between the federal Department of Education and the states' role in providing high-quality education and increasing educational opportunity.

Aside from challenges of the Common Core, there is a renewed sense among many educators that the states are "where the action is" and that on many matters the states can assess their needs, capacities, and priorities better than the federal government. This is not suggested in the spirit of a "kinder, gentler" face of the department or to "reduce" the federal role but to suggest some changes given the giant workload Common Core will generate for the districts and the states. Furthermore, in this past 23 years of standards-based reform, the states have had ample time to develop reform systems and accountability; most have more capacity than they have ever had.

One example of federal-state cooperation is suggested by a recent article about California having some documented success with a state program of more extensive on-site technical assistance in individual districts (Strunk and McEachin 2014). If such successes continue, the Department of Education could disseminate information about California and subsidize state education agencies so they can create such units or use California's insights to strengthen their present technical assistance programs.

The relationship between Common Core and the Department of Education will continue to exist. It is hard to imagine that there will not be issues where adjustments might have to be made in federal regulations or in Common Core procedures. One important area might be the relation of the Common Core's heightened standards to possible disparate effects on economically disadvantaged students, students 
of color, or other groups. Perhaps it would be appropriate for the department and the Common Core leaderships to collectively look at how the new, more challenging Common Core standards and activities are affecting the lowest achievers. One of the most important contributions the Department of Education has made during the long era of standards-based school reform has been, with the support of their Presidents, to press the states and districts to put special emphasis on helping lowachieving students coming from low-income families or students of color who so often encounter racial prejudice. I am confident that these and other issues are already under discussion as we move into a more collegial relationship between the department and the states. It will be interesting to see what the next reauthorization of ESEA says about the Common Core, and how the existence of the Common Core will impact on the Department of Education's requirements for receipt of grants such as for Title I.

One of the risks of relying more on the states to carry the ball in school reform is that the states' capacities are uneven, and they differ greatly in the achievement of their students and their progress in reform. The department could ameliorate that by incentivizing state action on various important national priorities. The incentives would be to subsidize the costs of introducing new or improved programs in return for reliable agreements to carry them out. The department could choose to start with two or three areas of reform. For example:

Early Childhood Education Individual states have been the leaders in the reform of early childhood education. (Rose 2010). The results have been quite different in these states that have led in attempting to upgrade early childhood opportunities by improving training and salaries, standards, and facilities. The federal government has endorsed this cause.

School Finance Equity Here again, some states are leaders and are well down the road that ran through many courtrooms. The idea of federal subsidies to help other states was raised in the Department of Education's Commission on School Finance a few years ago and would have the same effect as the early education option: stimulating reform and equalizing education across districts and across states (see Chap. 4).

Technical Assistance As mentioned above, another subsidization idea is to support the state education agencies in providing enhanced technical assistance to districts.

\section{Title I Improvements}

Congress and the administration should approve the continuation of Title I, at a higher level of authorization. As we have seen, there is much divided opinion about the effectiveness of Title I in reducing achievement gaps between race-ethnic groups and between students from varying family income groups (free lunch, partial free lunch, and not-free lunch). I am an outsider to this literature, but it seems that the 
lack of connection between Title I assignment and a student's race or family income level renders most research results inconclusive in judging Title I's effects. The federal government should make a major effort to support research that follows actual Title I students, tracking them through Title I instruction, and probing why children of color are now making better progress on improving scores and narrowing gaps, while children from families with low income are not.

Income inequality, increasing since 1980, has devastating effects on most people in the lowest one-fifth of the population and even above that. With people facing difficulties related to low wages, unemployment, housing, and health care, this would be an illogical time to decrease our support for our main educational program aimed at children from poor families.

\section{Additional Legislation}

Major legislation regarding other programs that have attempted to lessen educational disadvantages and bias should be enacted. I do not know as much about current policy controversies in these fields as I do about Title I. I should simply like to say that, as a historian, I believe that the programs included in this essay have achieved historically important breakthroughs yet still need further extension and reform. Because their principal object is to ensure specific group rights and they have been underfunded in the past, I believe that programs regarding these issueseducation of children with disabilities; bilingual education and other recognition of the needs of English language learners; women's rights in education and their enforcement, and the improvement of Native American educational resources and governance-should be amply funded to the fullest extent allowed by the resources of the Congress and the nation.

\section{Conclusion}

The goal of this chapter was to assess the major efforts by the federal government (with an eye on major advances by the states) to widen educational opportunity. Efforts through the decades have been filled with frustrations, controversies, and imperfections. But in the end, I see progress. Despite their failings, I have come out of the process, on balance, more hopeful about the positive effects these initiatives might still provide.

Open Access This chapter is distributed under the terms of the Creative Commons AttributionNoncommercial 2.5 License (http://creativecommons.org/licenses/by-nc/2.5/) which permits any noncommercial use, distribution, and reproduction in any medium, provided the original author(s) and source are credited.

The images or other third party material in this chapter are included in the work's Creative Commons license, unless indicated otherwise in the credit line; if such material is not included in the work's Creative Commons license and the respective action is not permitted by statutory regulation, users will need to obtain permission from the license holder to duplicate, adapt or reproduce the material. 


\section{References}

Aron, Lauden, and Pamela Loprest. 2012. Disability and the education system. The Future of Children 22(1): 110.

Baker, Bruce D., David G. Sciarra, and Danielle Farrie. 2014. Is school funding fair? A national report card. Newark: Education Law Center. http://www.schoolfundingfairness.org

Barley, Numan V. 1997. The rise of massive resistance: Race and politics in the South during the 1950s, 2nd ed. Baton Rouge: Louisiana State University Press.

Baugh, Joyce A. 2011. The Detroit school busing case: Milliken v. Bradley and the controversy over desegregation. Lawrence: University Press of Kansas.

Beaton, Albert E., and James R. Chromy. 2010. NAEP trends: Main NAEP vs. long-term trend. Paper for the NAEP Validity Studies Panel, American Institutes for Research, for National Center for Education Statistics. http://www.air.org/resource/ naep-trends-main-naep-vs-long-term-trend

Bell, Theodore, to David Grinstead (White House staff). 1975. Folder 5, Box 801, Office Files of the Commissioner of Education, National Archives and Records Administration, College Park, November 21.

Bestor, Arthur. 1953. Educational wastelands: The retreat from learning in our schools. Urbana: University of Illinois Press.

Borman, Geoffrey D., and Jerome D’Agostino. 1996. Title I and student achievement: A metaanalysis of federal evaluation results. Educational Evaluation and Policy Analysis 18(4): 309-326.

Bound, John, and Sarah Turner. 2002. Going to war and going to college: Did World War II and the GI Bill increase educational attainment of returning veterans?". Journal of Labor Economics 20(4): 784-815.

Carnoy, Martin, and Susanna Loeb. 2002. Does external accountability affect student outcomes? A cross-state analysis. Educational Evaluation and Policy Analysis 24 (4: 305f). http://epa.sagepub.com/content $/ 24 / 4 / 305$

Carter, Launor F. 1984. The sustaining effects study of compensatory and elementary education. Educational Researcher 13(7): 4-13.

Cascio, Elizabeth U., Nora Gordon, and Sarah Reber. 2013. Local responses to federal grants: Evidence from the introduction of Title I in the South. American Economic Journal: Economic Policy 5(3): 121-159.

Clarke, Marguerite. 2007. State responses to the No Child Left Behind Act: The uncertain link between implementation and 'Proficiency for All.' In Kaestle and Lodewick 2007, 144-76.

Clotfelter, Charles T. 2004. After Brown: The rise and retreat of school desegregation. Princeton: Princeton University Press.

Cohen, David K., and Susan L. Moffitt. 2009. The ordeal of equality: Did federal regulation fix the schools? Cambridge, MA: Harvard University Press.

Conant, James B. 1959. The American high school today. New York: McGraw-Hill.

Costain, Anne. 1979. Eliminating sex discrimination in education: Lobbying for implementation of Title IX. In Race, sex, and policy problems, ed. Marian Lief Palley and Michael B. Preston. Lexington: Lexington Books.

Cross, Christopher T. 2014. Political education: Setting the course for state and federal policy, 2nd ed. New York: Teachers College Press.

Cubberley, Ellwood P. 1909. Changing conceptions of education. Boston: Houghton Mifflin.

Davies, Gareth. 2007. See government grow: Education politics from Johnson to Reagan. Lawrence: University Press of Kansas.

DeBray, Elizabeth H. 2006. Politics, ideology, \& education: Federal policy during the Clinton and Bush administrations. New York: Teachers College Press.

Dee, Thomas S., and Brian Jacob. 2011. The impact of no child left behind on student achievement. Journal of Policy Analysis and Management 30(3): 418-446.

Dougherty, Jack. 2004. More than one struggle: The evolution of Black school reform in Milwaukee. Chapel Hill: University of North Carolina Press. 
Douglas, Davison M. 1995. Reading, writing, and race: The desegregation of the Charlotte schools. Chapel Hill: University of North Carolina Press.

Dwyer, Carol Anne (ed.). 2005. Measurement and research in the accountability era. Mahwah: Lawrence Erlbaum Associates.

Eidenberg, Eugene, and Roy D. Morey. 1969. An act of Congress: The legislative process and the making of education policy. New York: Norton.

Executive Office of the President of the United States. 2009. Educational impact of the American Recovery and Reinvestment Act. A report issued by the Domestic Policy Council, October. www.whitehouse.gov/assets/FDPC_Education/Report.pdf

Federal Education Policy and the States, 1945-2009. 2009. States' impact on federal education policy project. http://nysa32.nysed.gov/edpolicy/research/es_essay_reagan_achvmnt-gap. shtml

Ferguson, Ronald F. 1998. Can schools narrow the Black-White test score gap? In Jencks and Phillips 1998, 318-74.

Ferguson, Ronald F., and Jal Mehta. 2004. An unfinished journey: The legacy of Brown and the narrowing of the achievement gap. Phi Delta Kappan 85(9): 656-669.

Fishel, Andrew, and Janice Pottker. 1977. National politics and sex discrimination in education. Lexington: Lexington Books.

Frum, David. 2000. How we got here: The 70's. New York: Basic Books.

Gamson, David. 2007. From progressivism to federalism: The pursuit of equal educational opportunity, 1915-1965." In Kaestle and Lodewick 2007.

Goertz, Margaret E. 2005. Implementing the No Child Left Behind act: Challenges for the states. Peabody Journal of Education 80(2): 73-89.

Goldin, Claudia, and Lawrence F. Katz. 2008. The race between education and technology. Cambridge, MA: Harvard University Press.

Gordon, Nora. 2004. Do federal grants boost school spending? Evidence from Title I. Journal of Public Economics 88: 1771-1792.

Graham, Hugh Davis. 1990. The civil rights era: Origins and development of national policy. New York: Oxford University Press.

Hale, Lorraine. 2002. Native American education: A reference handbook. Santa Barbara: ABC CLIO.

Hawkins, Augustus Freeman (Gus), (1907-2007). n.d. Biographical directory of the United States Congress. http://bioguide.congress.gov/scripts/biodisplay.pl?index $=\mathrm{h} 000367$

Hedges, Larry V., and Amy Nowell. 1998. Black-White test score convergence since 1965. In Jencks and Phillips 1998, 149-181.

Jeffrey, Julie Roy. 1978. Education for children of the poor: A study of the origins and implementation of the Elementary and Secondary Education Act of 1965. Columbus: Ohio State University Press.

Jencks, Christopher, and Meredith Phillips (eds.). 1998. The Black-White test score gap. Washington, DC: Brookings Institute Press.

Jennings, John F. 1998. Why national standards and tests: Politics and the quest for better schools. Thousand Oaks: Sage.

Jennings, Jack. 2015. Presidents, Congress, and the public schools: The politics of education reform. Cambridge, MA: Harvard Education Press.

Kaestle, Carl F. 2012 Testing policy in the United States: A historical perspective. Paper prepared for the Gordon Commission on the Future of Educational Assessment. http://www.gordoncommission.org/publications_reports/assessment_education.html

Kaestle, Carl F. 1983. Pillars of the Republic: Common Schools and American Society, 1780 1860. New York: Hill \& Wang.

Kaestle, Carl F. 1990. The public schools and the public mood. American Heritage 41: 1.

Kaestle, Carl F. 1995. Literate America: High-level adult literacy as a national goal. In Learning from the past: What history teaches us about school reform, ed. Diane Ravitch and Maris Vinovskis, 329-354. Baltimore: Johns Hopkins University Press. 
Kaestle, Carl F. Forthcoming. Uncertain mandate: The formative years of the federal role in education.

Kaestle, Carl F., and Alyssa E. Lodewick (eds.). 2007. To educate a nation: Federal and national strategies of school reform. Lawrence: University Press of Kansas.

Kaestle, Carl F., and Larry Stedman. 1987. Literacy and reading performance in the United States, from 1880 to the present. Reading Research Quarterly 22(Winter): 8-46.

Kaestle, Carl F., and Maris A. Vinovskis. 1980. Education and social change in 19th-century Massachusetts. Cambridge: Cambridge University Press.

Kober, Nancy. 2001. It takes more than testing: Closing the achievement gap. Washington, DC: Center on Education Policy.

Krug, Edward. 1964. The shaping of the American high school. New York: Harper \& Row.

Linn, Robert. 2005. Scientific evidence and inference in educational policy and practice: Implications for evaluating adequate yearly progress. In Dwyer 2005, 24.

Lubienski, Christopher A., and Sarah Theule Lubienski. 2014. The public school advantage: Why public schools outperform private schools. Chicago: University of Chicago Press.

Manna, Paul. 2007. School's in: Federalism and the national education agenda. Washington, DC: Georgetown University Press.

Martin, Ruby, and Phyllis McClure. 1969. Title I of ESEA: Is it helping poor children? Washington, DC: Washington Research Project and the NAACP Legal Defense Fund.

Massey, Douglas S., Jonathan Rothwell, and Thurston Domino. 2009. "The changing base of segregation in the United States." Annals of the American Academy of Political and Social Science 626 (74). http://www.ncbi.nlm.nih.gov

McCarthy, Joseph Justin. 1991. Title IX from 1970 to 1988: A study in educational policy-making (doctoral dissertation). Cambridge, MA: Harvard Graduate School of Education.

McDonnell, Lorraine M. 2005. No Child Left Behind and the federal role in education: Evolution or revolution? Peabody Journal of Education 80(2): 19-38.

McGuinn, Patrick J. 2006. No Child Left Behind and the transformation of federal education policy, 1965-2008. Lawrence: University Press of Kansas.

McLaughlin, Milbrey W. 1975. Evaluation and reform: The Elementary and Secondary Education Act of 1965. Cambridge: Ballenger Publishing.

Miech, Edward J. n.d. The necessary gentleman: Francis Keppel's leadership in getting education's act together (doctoral dissertation). Cambridge, MA: Harvard University, Graduate School of Education.

Miguel, San, and Jr. Guadalupe. 2004. Contested policy: The rise and fall of federal bilingual education in the United States. Denton: University of North Texas Press.

Moreno, José F. (ed.). 1999. The elusive quest for equality: 150 years of Chicano/Chicana Education. Cambridge, MA: Harvard Educational Review.

New America Foundation. n.d. Cost of educating children with disabilities. http://febp.newamerica.net/background-analysis/individuals-disabilities-education-act-funding-distribution

Orfield, Gary. 1969. Reconstruction of Southern education: The schools and the 1964 Civil Rights Act. New York: Wiley-Interscience.

Orfield, Gary, and Susan E. Eaton. 1996. Dismantling desegregation: The quiet reversal of Brown v. Board of Education. New York: New Press.

Orfield, Gary, Erica Frankenberg, Jongyeon Ee, and John Kuscera. 2014. Brown at 60: Great progress, a long retreat and an uncertain future. Los Angeles: University of California at Los Angeles.

Parrish, Thomas B. 2001. Who's paying the rising cost of special education? Journal of Special Education Leadership 14(1): 4-12.

Patterson, James T. 1996. Grand expectations: The United States, 1945-1974. New York: Oxford University Press.

Patterson, James T. 2001. Brown v. Board of Education: A civil rights milestone and its troubled legacy. New York: Oxford University Press.

Peterson, Paul. 1983. Background paper. In Making the grade: Report of the 20th century fund task force on federal elementary and secondary education policy. New York: 20th Century Fund. 
Porter, Andrew. 1995. The uses and misuses of opportunity-to-learn standards. Educational Researcher 24(1): 21-27.

Porter, Andrew. 2005. Prospects for school reform and closing the achievement gap. In Dwyer 2005.

Pottinger, Stanley. 1970. Memo regarding language minority children, May 25. http://www2. ed.gov/pint/about/offices/list/ocr/docs/lau1970.html

President's Commission on School Finance. 1972. Schools, people, \& money: The need for educational reform. Washington, DC: U.S. Government Printing Office.

Ravitch, Diane. 1995. National standards in American education: A citizen's guide. Washington, DC: Brookings Institution.

Reardon, Sean F. 2011. The widening achievement gap between the rich and the poor: New evidence and possible explanations. In Whither opportunity: Rising inequality, schools, and children's life chances, ed. Greg J. Duncan and Richard J. Murnane, 91-116. New York: Russell Sage Foundation/Spencer Foundation.

Reardon, Sean F., Elena Tej Grewal, Demetra Kalogrides, and Erica Greenberg. 2012. Brown fades: The end of court-ordered school desegregation and the resegregation of American public schools. Journal of Policy Analysis and Management 31(4): 533-547.

Reese, William J. 1995. The origins of the American high school. New Haven: Yale University Press.

Reese, William J. 2013. Testing wars in the public schools: A forgotten history. Cambridge, MA: Harvard University Press.

Rose, Elizabeth. 2010. The promise of preschool: From Head Start to universal pre-kindergarten. New York: Oxford University Press.

Rothman, Robert. 2011. Something in common: The Common Core standards and the next chapter in American education. Cambridge, MA: Harvard Education Press.

Rothstein, Richard. 2004. Class and schools: Using social, economic and educational reform to close the Black-White achievement gap. Washington, DC: Economic Policy Institute.

Rury, John L. 2005. Education and social change: Themes in the history of American schooling, vol. 2. Mahwah: Lawrence Erlbaum.

Salomone, Rosemary C. 1986. Equal education under law: Legal rights and federal policy in the post-Brown era. New York: St. Martin's Press.

San Miguel Jr., Guadalupe. 1987. 'Let all of them take heed' Mexican Americans and the campaign for educational equality in Texas, 1910-1981. Austin: University of Texas Press.

Schneider, Susan Gilbert. 1976. Revolution, reaction or reform: The 1974 Bilingual Education Act. New York: Las Americas Publishing Company.

Scotch, Richard K. 2001. From good will to civil rights: Transforming federal disability policy, 2nd ed. Philadelphia: Temple University Press.

Simon, Kenneth A., and W. V. Grant (eds.). 1970. Digest of educational statistics. Washington, DC: Office of Education.

Smith, Marshall S., and Jennifer A. O'Day. 1991. Systemic school reform. In The politics of curriculum and testing, Politics of education association yearbook 1990, ed. Fuhrman Susan and Malen Betty, 233-267. London: Falmer Press.

Stewner-Manzanares, Gloria. 1988. The bilingual education act: Twenty years later. In Occasional Papers in Bilingual Education 6 (Fall). Washington, DC: Office of Bilingual Education and Minority Languages Affairs. http://eric.ed.gov/?id=ED337031

Strum, Phillipa. 2010. Mendez v. Westminster: School desegregation and Mexican-American rights. Lawrence: University Press of Kansas.

Strunk, Katherine O., and Andrew McEachin. 2014. More than sanctions: Closing achievement gaps through California's use of intensive technical assistance. Education Evaluation and Policy Analysis 36(3): 281-307.

Sundquist, James L. 1968. Politics and policy: The Eisenhower, Kennedy and Johnson Years. Washington, DC: Brookings Institution.

Swanson, Beverly B. 1991. An overview of the six national education goals. ERIC Digest. www. ericdigests.org/pre-9220/six.htm 
Szasz, Margaret Connell. 1999. Education and the American Indian: The road to self-determination since 1928, 3rd ed. Albuquerque: University of New Mexico Press.

Turnbull, Brenda J., and Ellen L. Marks. 1986. The education block grant and intergovernmental relations: Effect at the local level. Menlo Park: SRI International.

Turner, Susan, and John Bound. 2003. Closing the gap or widening the divide: The effects of the G. I. Bill and World War II on educational outcomes of Black Americans. Journal of Economic History 63(1): 145-177.

U.S. Department of Education, 2009. The American Recovery and Reinvestment Act of 2009: Saving and creating jobs and reforming education, March 7. www2.ed.gov/policy/gen/leg/ recovery/implementation.htm

U.S. Department of Education, National Center for Education Statistics. 2015a. Fast facts: Students with disabilities. (Source: Digest of Education Statistics, 2012). https://nces.ed.gov/fastfacts/ display.asp?id=64

U.S. Department of Education, National Center for Education Statistics. 2015b. What are the differences between long-term trend NAEP and main NAEP? National Assessment of Educational Progress. Accessed January 27, 2015. http://nces.ed.gov/nationsreportcard/about/ltt_main_ diff.aspx

U.S. Department of Health, Education, and Welfare, Office of Civil Rights. 1975. Task-force findings specifying remedies available for eliminating past educational practices rule unlawful under Lau v. Nichols. Copy in Bilingual education: A reappraisal of federal policy, edited by Keith A. Baker and Adriana A. de Kanter. Lexington: Lexington Books, 1983, Appendix B.

Urban, Wayne. 2010. More than science and Sputnik: The National Defense Education Act of 1958. Tuscaloosa: University of Alabama Press.

Verstegen, Deborah A. 1985. Redistributing federal aid to education: Chapter 2 of the Education Consolidation and Improvement Act of 1981. Journal of Education Finance 10(4).

Vinovskis, Maris A. 1999a. Do federal compensatory education programs really work? A brief historical analysis of Title I and Head Start. American Journal of Education 107(3): 187-209.

Vinovskis, Maris A. 1999b. History \& educational policymaking. New Haven: Yale University Press.

Vinovskis, Maris A. 2008. Gubernatorial leadership and American K-12 educational reform. In Legacy of innovation: Governors and American public policy, ed. Ethan Scribnick, 185-203. Philadelphia: University of Pennsylvania Press.

Vinovskis, Maris A. 2009. From A Nation at Risk to No Child Left Behind: National education goals and the creation of federal education policy. New York: Teachers College Press.

Ware, Susan (ed.). 2007. Title IX: A brief history with documents. Boston: Bedford-St. Martin's.

Webb, Clive (ed.). 2005. Massive resistance: Southern opposition to the second reconstruction. New York: Oxford University Press.

Wilkinson III, J. Harvie. 1979. From Brown to Bakke: The Supreme Court and school integration, 1954-1978. Oxford: Oxford University Press. 